\title{
A REVIEW OF THE SPECIES OF ACROMETOP $A$ FIEBER, 1853 (ORTHOPTERA, TET'TIGONIOIDEA, PHANEROPTERINAE) WITH SPECIAL REFERENCE TO THE GREEK FAUNA
}

\author{
by \\ FER WILLEMSE \\ Laurastraat 67, Eygelshoven, The Netherlands
}

\begin{abstract}
The characters previously used for the distinction of the species of Acrometopa are reviewed and modified differential diagnoses are given. Neotypes for $A$. macropoda (Burmeister) and $A$. servillea (Brullé) and a lectotype for $A$. syriaca Brunner von Wattenwyl are designated. From the Aegean island of Ikaría $A$. cretensis daedali nov. subsp. is described, and a key to the species and subspecies is given. The geographical variation within $A$. macropoda is described and discussed. A critical review of previous records in literature, together with the addition of new distributional data from Greece, has brought more logic in the known distributional pattern of the species.
\end{abstract}

\section{INTRODUCTION}

During the examination of a rich material of Acrometopa from Greece it became apparent that certain characters which had been considered of diagnostic value for the distinction of the species were not reliable. Moreover, evidence was found that the geographical variation in Acrometopa macropoda is considerably larger than was understood previously.

These conditions induced a renewed evaluation of the diagnostic characters of the taxa within the genus and a review of their differential diagnoses. The present paper gives the results of this study, which includes a re-examination of the typematerial of most of the species involved. In addition an attempt is made to clarify the hitherto somewhat erratic picture of the distribution of the species.

\section{MATERIAL AND ACKNOWLEDGEMENTS}

The material on which this paper is based consists of $188 \hat{\delta}$ and $150 \%$ specimens in the author's collection (CW). Most of this has been collected in Greece by the author himself and his son Lucas in the years 1966 and 1969 to 1977, between the 1st of July and the 11 th of August. In addition $64 \hat{\delta}$ and 43 of specimens were borrowed from the institutions listed below (the abbreviations used in the following text are given in parentheses) :
Naturhistorisches Museum, Wien (NMW); Instituut voor Taxonomische Zoölogie, Amsterdam( ZMA); Istituto Policattedra di Biologia Animale, Catania (IBA); British Museum (Natural History), London (BMNH); Hope Department of Entomology, University Museum, Oxford (HMO); Natuurhistorisch Museum, Maastricht (NMM).

For the loan of material thanks are due to Dr. A. Kaltenbach, Vienna, Dr. G. Kruseman, Amsterdam, Dr. M. La Greca, Catania, Mrs. L. Pitkin, London, and Dr. C. O'Toole, Oxford. For valuable information on type-material I am much indebted to Dr. M. Descamps, Paris, and Dr. M. Dohrn, Halle-Wittenberg, and to the Institut für Pflanzenschutzforschung, Eberswalde (DDR).

\section{SYSTEMATIC PART}

\section{Acrometopa Fieber, 1853}

Acrometopa Fieber, 1853: 172; Brunner von Wattenwyl, 1878: 14, 85; 1882: 189, 246; 1891: 5; Ramme, 1927: 119; Beî-Bienko, 1954: 56, 121; Harz, 1969: 8, 18.

Type-species: Phaneroptera macropoda Burmeister, 1838.

Description. - A general description of the genus can be found in the references listed above. Some additional information, however, is required.

In the fore wing of the male the basal parts of the radial and medial areas have a series of sinuate and about parallel transverse veins with interspaces almost completely transparent and lacking the archedictyon which occupies the remainder of the wing (figs. 1-2). The bases of the anal, $\mathrm{Cu} 2$ and Cu1b areas are transformed into the stridulatory apparatus (figs. 4-5). The $\mathrm{Cu} 2$ vein of the left wing has become the stridulatory file (figs. 8-13). The file is slightly arcuate both horizontally and vertically, and divided into a wider anterior part with less numerous coarse teeth and a narrower posterior part with numerous, closely set fine teeth. The $\mathrm{Cu} 2$ vein of the right wing, often with traces of teeth, is strongly convex ventrally and bears in its middle a strongly sclerotized knob (figs. 6-7). Origin and function are unknown. The greater 
part of the Cu1b area of the right wing is transformed into the mirror, and part of the hind margin of the wing, opposite the posteroproximal border of the mirror, into the scraper. Whereas the surfaces of the anal, $\mathrm{Cu} 2$ and $\mathrm{Cu} 1 \mathrm{~b}$ areas of the left wing are almost similar and horizontal, the conditions in the right wing are different. In the latter the $\mathrm{Cu} 2$ and $\mathrm{Cu} 1 \mathrm{~b}$ areas are obliquely vertical as a result of the convex course of the $\mathrm{Cu} 2$ vein.

In the female the fore wing is much shorter than in the male. The radial and medial areas are not modified as conspicuously as in the male and the archedictyon covers the whole wing (fig. 3). The stridulatory apparatus consists of series of small spines on the dorsal surface of the veins near the hind margin of the cubito-anal areas of the right wing.

The general colour of the male is bright green; the female is darker green, often with a bluish tinge. Brown specimens may occur but are very rare.

Distribution. - The range of the genus includes Corse, Sardegna, Sicilia, Italy, the coastal areas of Yugoslavia and Albania, Greece, Turkey, Cyprus, Syria, the Lebanon and Israel, and extends into Iraq and Egypt.

In the lists of material of the species the Greek localities are numbered, referring to the distribution map. The transcription of the Greek names is brought in accordance with the system adopted by the Permanent Committee on Geographical Names for British Official Use, London.

Stridulation. - Since the morphology of the male stridulatory file is quite different in various species, one might expect differences in the stridulation accordingly. We have heard the song of Acrometopa macropoda. $A$. servillea, $A$. syriaca and $A$. cretensis but without direct comparison we could not notice any dissimilarity.

The song of Acrometopa is quite characteristic. It lasts about five to ten seconds and ends in a peculiar, sharp metallic click which is characteristic for the genus. It is heard most frequently during twilight and in the night.

Krauss (1878: 502) compared the song of Acrometopa macropoda with that of Tettigonia cantans
(Fuessly). However, the sound of $A$. macropoda is by far not as loud as that of $T$. cantans and quite more frequently interrupted. The remarks by Burr (Burr, Campbell \& Uvarov, 1923: 126) are more exact. He compared the timbre and nature of the song of $A$. servillea with that of Phaneroptera, $A$. servillea stridulating relatively louder and stronger.

Specific characters and classification. - In his revision of the genus Ramme (1927) emphasized the diagnostic value of a number of characters, viz. the shape and the apical structure of the male cercus, the shape of the male subgenital plate, the length and shape of the wings in both sexes, the length and curvation of the ovipositor and the presence or absence of a small triangular projecting lobe at the base of the ovipositor.

In the course of the present study it became apparent that, due to a wide intraspecific variation, some of these characters are not reliable. The shape of the male subgenital plate cannot be used to distinguish $A$. italica, $A$. macropoda and $A$. servillea from each other. The same applies to the length and shape of the wings, although the female of $A$. cretensis is distinguished by comparatively longer hind wings. Particulars of the ovipositor which were supposed to be distinctive by Ramme (1927: figs. 8a-8e) are actually subject to considerable infraspecific variation. However, the projecting lobe at the base of the ovipositor is a reliable feature. The shape of the male cercus and the structure of its apex have proved to be the most useful and reliable diagnostic characters in the genus.

A further diagnostic feature is provided by the morphology of the male stridulatory file. This serves well for separating the males of $A$. macropoda, $A$. italica and $A$. servillea (figs. 10-11), from $A$. syriaca (figs. 8-9) and $A$. cretensis (figs. 12-13), but cannot be used for the distinction of the three first mentioned species.

With the aid of the characters mentioned the species of Acrometopa can be separated satisfactorily, although the distinction between the females of $A$. italica, $A$. macropoda and $A$. syriaca remains doubtful. The general habit of $A$. syriaca is usually more robust, and $A$. italica is generally 


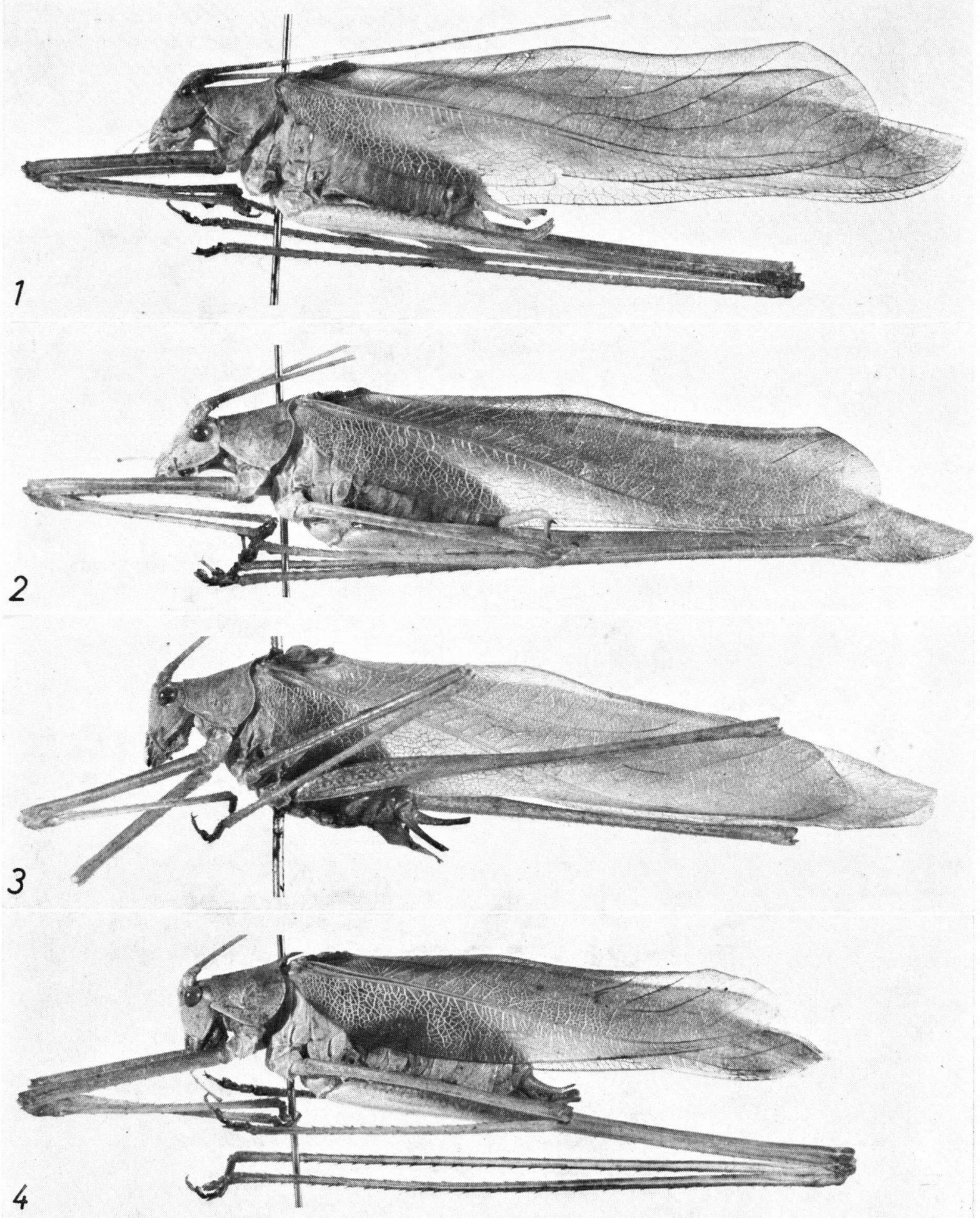

Plate I figs. 1-4. Acrometopa: 1, A. macropoda (Burmeister), neotype; 2, A. servillea (Brullé), neotype; 3, A. syriaca Brunner von Wattenwyl, lectotype; 4, A. cretensis daedali ssp. n., paratype. 
somewhat smaller than $A$. macropoda. However, robust female specimens of $A$. macropoda from Istra and slender females from northwestern Greece are indistinguishable from $A$. syriaca and A. italica, respectively.

On account of the structure of the cercus, the subgenital plate and the stridulatory file of the male three groups of species can be distinguished, viz.
(1) A. italica, $A$ macropoda and $A$. servillea,
(2) A. syriaca,
(3) A. cretensis cretensis and A. cretensis daedali.

The species of the first group have a parallelsided subgenital plate and a very characteristic stridulatory file, and the tip of the cercus is excavate: weakly in $A$. italica, moderately in $A$. macropoda and strongly in $A$. servillea. The species of the second and third groups differ from those of the first in the subgenital plate which narrows apically, and the solid tip of the cercus. The cercus is provided with two minute teeth in the second, and simply pointed in the third group. The most characteristic differences between the three groups are found in the structure of the stridulatory files.

Juvenile specimens in their last instar may be identified by particulars of the male cercus and the lobe at the base of the ovipositor, which are already recognizable.

\section{KEY TO THE SPECIES AND SUBSPECIES OF ACROMETOPA}

1. If stridulatory file either in the anterior half with three, or near the middle with two sinuate elevations and depressions (figs. 10-13) . . . . . . . . . 2

- $\delta$ stridulatory file in anterior half with very coarse, widely and regularly spaced teeth, without such elevations and depressions (figs. 8-9); $\hat{\sigma}$ cercus slightly incurved apically (fig. 42), terminating into a pair of minute, solid teeth (figs. 65-66); $\hat{o}$ subgenital plate with lobes distinctly narrowing apically (fig. 31 ); $\$$ without distinctly extending lobe between gonangulum and subgenital plate (fig. 26) (Egypt, Israel, the Lebanon, Syria, Iraq, Cyprus, Turkey, eastern Aegean islands, Greece: Thraki and Makedhonía, map) . A. syriaca Brunner von Wattenwyl

2. if stridulatory file with two sinuate elevations and depressions in the middle (figs. 10-11); $\hat{o}$ cercus with tip excavate, apical margin lamelliform (figs. 45-46); $\hat{\delta}$ subgenital plate with lobes about parallel-sided (figs. 28 $30)$; $q$ hind wing not extending beyond tip of fore wing . . . . . . . . . . . . . . . . . 4

- $\delta$ stridulatory file with three sinuate elevations and depressions in anterior half (figs. 12-13); $\delta$ cercus with apex solid and pointed (figs. 43-44); $\hat{\delta}$ subgenital plate with lobes slightly narrowing apically (figs. 32-33);

o hind wing extending beyond tip of fore wing . . 3

3. of cercus longer, strongly and evenly incurved all over its length (fig. 43) (Kriti and western Kikládhes, map) . . . . . . . . A. cretensis cretensis Ramme - $\delta$ cercus shorter, abruptly and almost rectangularly incurved just beyond middle of length (fig. 44) (Ikaria, map) . . . . . . . . A. cretensis daedali ssp. $\mathrm{n}$.

4. If cercus in apical fourth moderately to rectangularly incurved (figs. 34-40), tip wider and distinctly excavate with lamelliform margin terminating into a hollow, beakshaped process (figs. 45-61); $q$ with or without a distinctly extending lobe between gonangulum and subgenital plate (figs. 15-23) . . . . . . . . . . 5

- $\delta$ cercus in apical fourth slightly incurved (fig. 41), tip narrower and slightly excavate with lamelliform margin without beak-shaped terminal process but simply dentate (figs. 62-64); $\uparrow$ always without distinctly extending lobe between gonangulum and subgenital plate (figs. 24-25) (Corse, Sardegna, Sicilia, Italy, Dalmatia?) . . . . .

. . . . . . . . . . . Acrometopa italica Ramme

5. $\hat{o}$ cercus strongly, almost rectangularly incurved apically (figs. 38-40), with apex strongly excavate and lamelliform margin terminating in a long, beak-shaped, hollow process which is as long as or usually longer than the greatest width of apex of cercus (figs. 56-61); $q$ with a distinctly extending, roughly triangular lobe between gonangulum and subgenital plate, its size not smaller than in figs. 20-23 (from Syria, through Anatolia, the central and northern Aegean islands, into the Greek mainland east of a line running over the Píndhos range and, in same direction further southeastward, map) . . . . . . . Acrometopa servillea (Brullé)

- $\delta$ cercus less incurved (figs. 34-37), apex less excavate with beak-shaped process shorter (figs. 45.55); $f$ usually without, but in southern Greece with a small extending lobe between gonangulum and subgenital plate, its size never larger than in figs. 15-19 (from Istra along the Adriatic coast of Yugoslavia and Albania, Ionian islands and western Greece, west of range of $A$. servillea, Gargano area of Italy, map). - . . . Acrometopa macropoda (Burmeister)

\section{Acrometopa macropoda (Burmeister, 1838)}

(figs. 1-3, 15-19, 28, 34-37, 45-55, pl. I fig. 1, map)

Phaneroptera macropoda Burmeister, 1838: 689; Fischer, 1854: 237.

Phaneroptera dalmatina Serville, 1839: 415; Fischer, 1854 237.

Acrometopa macropoda macropoda: Ramme, 1927: 121, figs. $5 b-8 b, 9$.

Acrometopa macropoda; Uvarov, 1935: 75; La Greca, 1959: 101, fig. 113.

Acrometopa servillea; Brunner von Wattenwyl, 1878: 86; 1882: 290; Werner, 1902: 117; 1927: 428; Ramme, 1927: fig. 9; Werner, 1937a: 145; Beî-Bienko, 1954: 123 (all partim); Cejchan, 1963: 766.

Acrometopa italica; Kaltenbach, 1967: 189.

Material studied. - $\delta$ neotype, labelled: Jugoslavia (Crna Gora) Kotor $10 \mathrm{~m}$ 3.VIII.1963, F. Willemse (ZMA). 

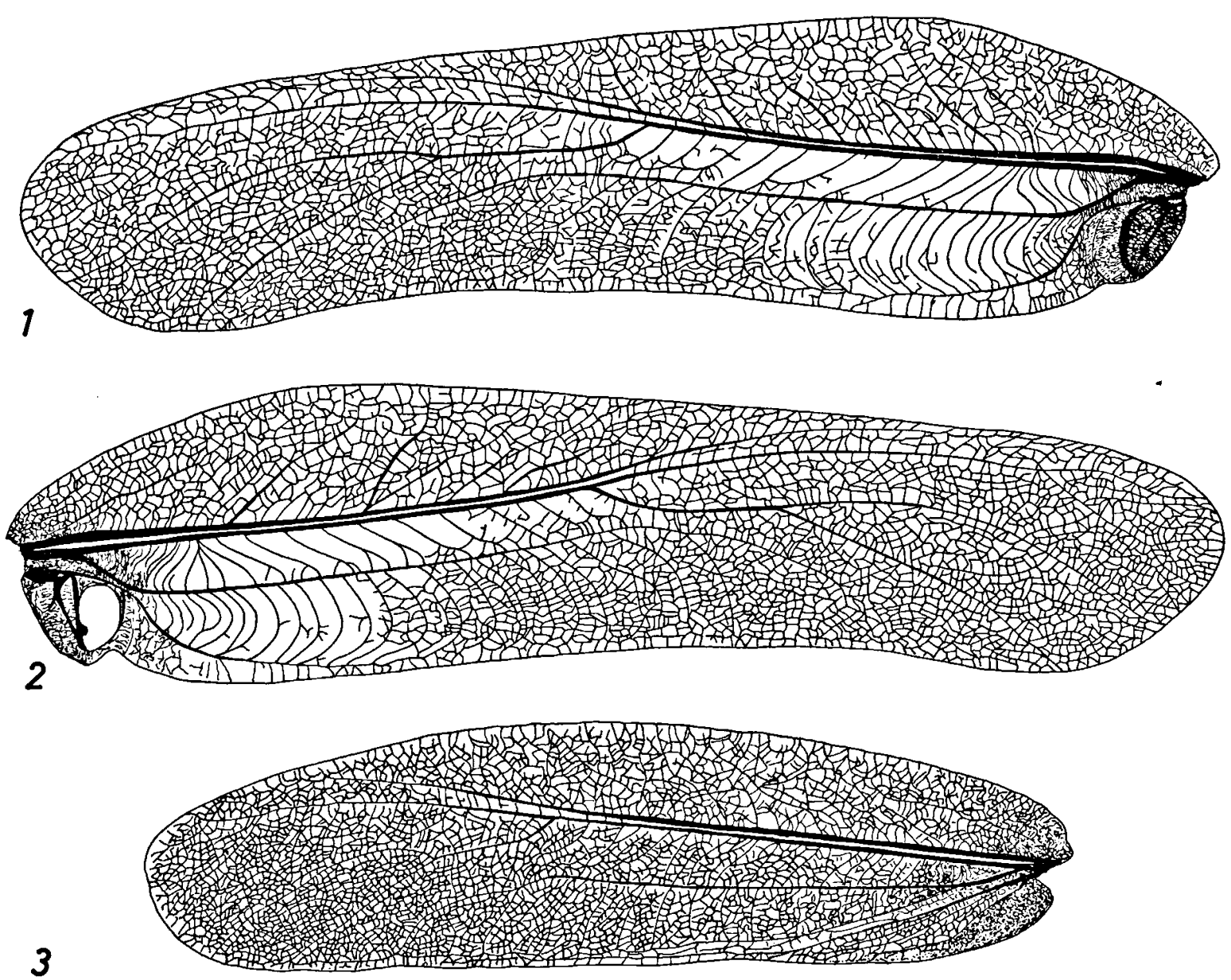

Figs. 1-3. Fore wing of Acrometopa macropoda (Burmeister) (Arkadhia, Trípolis), dorsal view: 1, left wing of $\hat{\delta} ; 2$, right wing of $\hat{o} ; 3$, left wing of $q$.

Yugoslavia: Istra: $2 \mathrm{~km}$ ESE of Valtura, 14.VII.1966, $7 \hat{\delta}, 4 \% ; 2 \mathrm{~km}$ W of Labin, 15.VII.1966, $19 ; 4 \mathrm{~km}$ NW of Vižinada, Mirna-Valley, 12.VII.1966, 1 (all ZMA); Učka, VII.1965, C. v. Demelt, 1 of; Kanegra, VII.1966, C. v. Demelt, 2 o (both CW); Dalmatia: -, $1 \hat{o}, 2$ q (BMNH); Brazza (= Brač), San Pietro - Neresi, 20.VII. 1912, 1 क (BMNH); Montenegro: Mucha, 1 ô; Krstač, $40 \mathrm{~km}$ NW of Nikšić $1000 \mathrm{~m}$, S.VIII.1968, Willemse c.s., 1 s (both $\mathrm{CW}$ ).

Italy: Is. Tremiti, S .Domino, 22.VI.1955, La Greca, 1 \%; Gargano, Sannicandro, 27.V.1957, La Greca, 1 î (both IBA), 4.VII.1977, F. \& L. Willemse, 1 ô, 1 \& (CW).

Albania: Çajup, 1.VIII.1935, A. G. H. Alston, $1 \hat{\delta}$ (BMNH).

Greece: Kérkira: (1a) Lake Antinioti, 2 ô, 1 \%; (1b) Lávkion, 1 ô; (1c) Kassiópi, 1 ô; (2a) Períthia, $5 \hat{\delta}, 3$ \%; (2b) Petália, 1 ô, 1 f; (2c) Yimárion, 5 ô; (3) Gazátika, 6 ô, 2 \&; (4a) Kastellánoi, 1 ô (all CW); (4b) Benítzai (= Benitzes), 24.VII.1965, A. Kaltenbach, A. italica Ramme det. A. Kaltenbach, 1 \& (NMW); (5) Lake Korissíon, 1 \%; Levkás: (6) Nikiána, $\mathrm{N}$ of Nidrion, 3 ô, 5 \%; (7) Âno Exánthia, 5 \& , 9 \%; Ioánnina: (8) river Sarandáporos, $\mathrm{N}$ of
Kónitsa, 1 ô ; (9) Kalpákion, 2 \&; (12) Asfáka, 2 \%; (11) Méga Peristérion, 1 ₹ (all CW); (10) Arísti, $700 \mathrm{~m}$, 2.VIII. 1973, La Greca, 1 우 (IBA); (13) Koutselión, 1 ô ; (14) Kaléntzion, 1 \%; Årta: (15) Ramía-Livádhion, 1 ô; Préveza: (16) Panayía, 1 ; Aitolia-Akarnanía: (17) Āktion, $1 \hat{\delta}, 2$; (18) Kokkinokhóri, 7 ิิ, 5 ९; Evritanía: (19) Proussós, $1 \hat{o}$; (20) Timfristós, above the village, $1 \hat{\delta}, 2$ q; Fokís: (21) Strómi-Moussounítsa, 1 \% ; Voiotia: (22) Mt. Parnassós, plateau above Arákhova, 5 ô, $3 \&$ (all CW), 17.VII. 1975, J. P. Duffels, 1 ô (ZMA), - (= Parnass), Krüper, coll. Br. v. W., Acrometopa servillea Brullé det. Br. v. W., 1 ô, 1 f (NMW); Akhaía: (23) Mt. Panakhaïkón, above Romanoú, 1 \&, above Zástova, 3 ô, 1 \& (CW), $1200 \mathrm{~m}$, 19.VIII.1973, La Greca-Messina, 1 ô (IBA); (24) Dhiakoptón, VII.1938, O. Grebenchikoff, 1 ô, 1 \& (BMNH); (25) Mt. Aroánia, Káto Loúsoi, above Kalávrita, 1 \% ; (26) Aroanía village, $3 \hat{\delta}, 2$ 우 (27) Kaléntzi, 1 ô, 5 우; (28) Skiadhá, 2 ô; (29) Potamía, 2 \&; Ilía: (30) Mármara, 1 ô, 2 \%; (31) Lálas, 2 \&; (32) Lekhainá, 1 ô ; (33) Kallithéa, 4 ô, 6 \%; (34) Figalía, ruins Vassae, 7 o, 3 \&; Arkadhia: (35) Vlákhoi, 1 \%; (36) Ipsoús, $3 \hat{\delta}, 1$ 우 ; (37) KarítainaRóvia, 4 ô, 4 ㅇ (38) Khrisovítsi, $5 \mathrm{~km} \mathrm{E-12} \mathrm{km} \mathrm{W,} 4$ ô, 

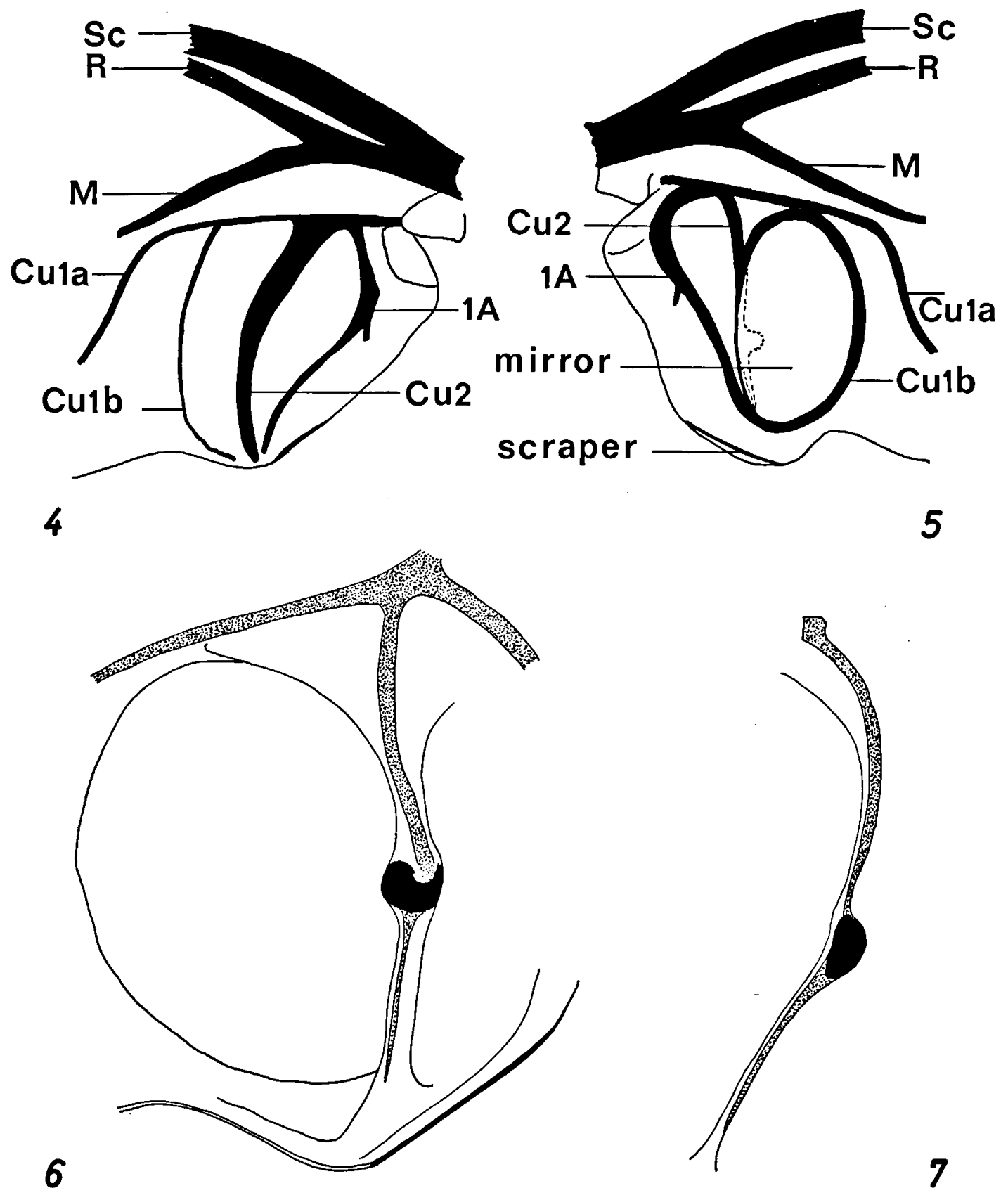

Figs. 4-7. Male stridulatory organ of Acrometopa: 4-5, dorsal view of base left (4) and right (5) fore wing; 6-7, Cu2 vein of right fore wing in ventral view (6) and profile (7). ( $1 \mathrm{~A}=$ first anal; $\mathrm{Cu}=$ cubitus; $M=$ medius; $R=$ radius: $\mathrm{Sc}=$ subcosta).

5 \&; (39) Kardhará, 2 ô, 1 \&; (40) Trípolis, $3 \mathrm{~km} \mathrm{E} \mathrm{\&}$ $5 \mathrm{~km} \mathrm{~W}, 27 \delta, 10$ \% (all CW), $3-8 \mathrm{~km} \mathrm{NW}, 800 \mathrm{~m}$, 13.VII.1975, J. P. Duffels, 1 \&, 1 \& (ZMA); Messinía: (41) Kámbos, $3 \hat{\delta, ~} 9$ $\uparrow$ (CW), VI.1901, Höltz, $1 \hat{\delta}$ (NMM); (42) Exokhóri (= Xechori), 5.VI.1937, F. Werner, Acrometopa servillea Brullé det. Werner, 1 ô, 1 \% (NMW); (43) Kalámai-Spárti, 2 ồ Lakonía: (44) Mistrás,
1 9; (45) Tópitza, above Anóyia, 5 ô, 11 \& (all CW); (46) Monemvasía, 25.V.1937, F. Werner, Acrometopa servillea Brullé det. Werner, 2 \& (NMW); Argolís: (47) E of Akhladhókambos, 2 \&, 2 \% (CW); Kíthira: (48) - (= Kythira = Cerigo), Acrometopa servillea Brullé det Br. v. W., 1 of, 1 , 27.V.1937, F. Werner, Acrometopa servillea Brullé det. Werner, 1 of (NMW). 


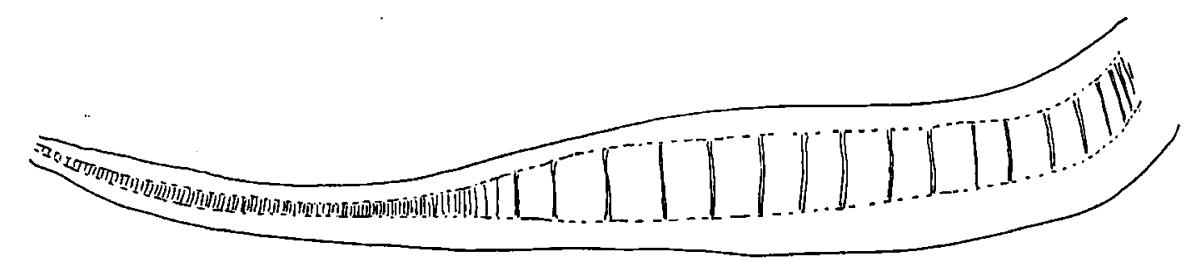

$\boldsymbol{8}$

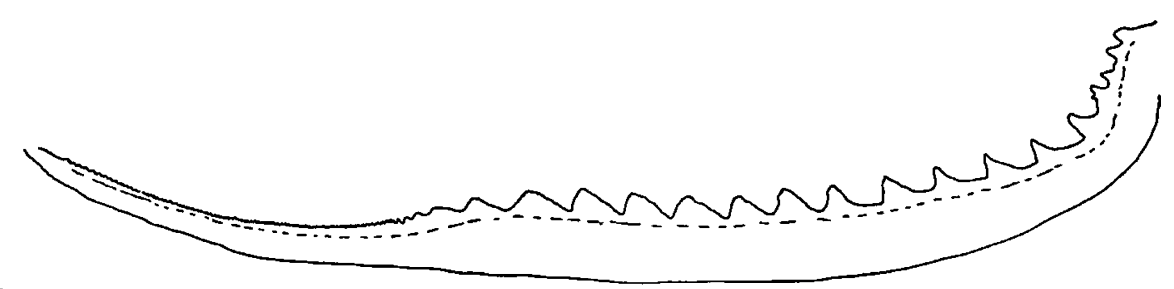

9

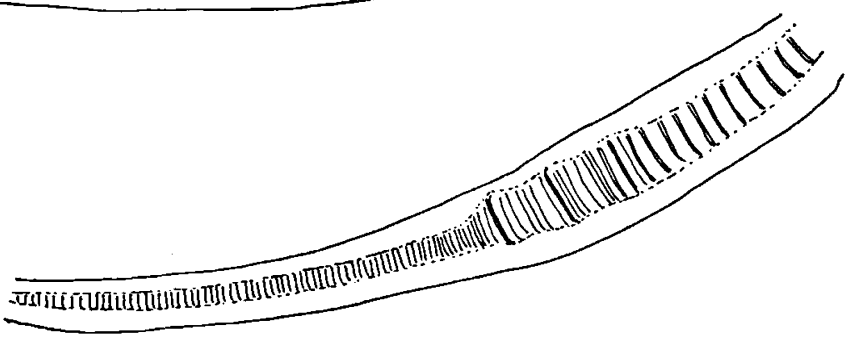

12

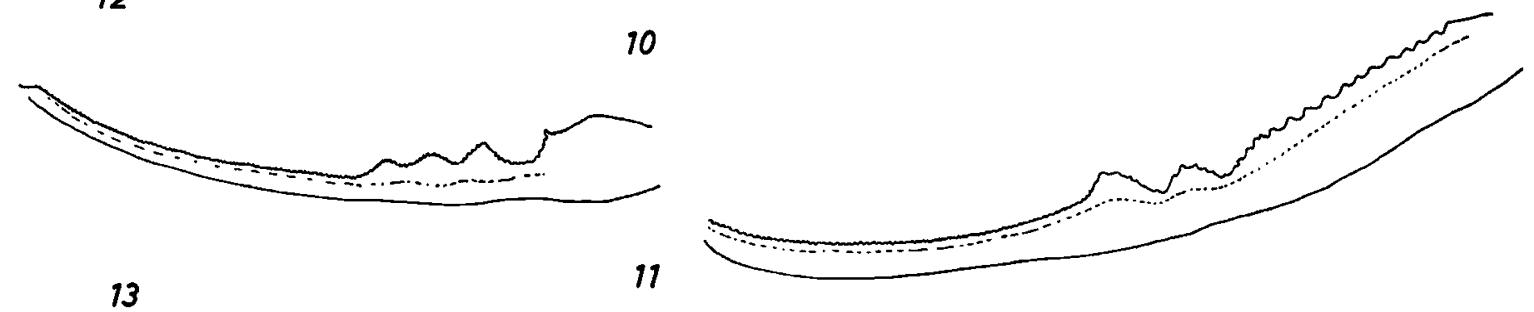

Figs. 8-13. Male stridulatory file of Acrometopa, ventral view (even numbers) and profile (odd numbers): 8-9, A. syriaca Brunner von Wattenwyl (Piéria, Litókhoron); 10-11, A. servillea (Brullé) (ibidem); 12-13, A. cretensis daedali ssp. n. (paratype).

Diagnosis. - $\delta$ : Stridulatory file in the middle with two sinuate elevations alternating with depressions (figs. 10-11). Cercus in apical fourth moderately incurved (figs. 34-37); apex excavate, lamelliform margin terminating in a beak-shaped process of moderate length (figs. 45-55). Lobes of subgenital plate parallel-sided (fig. 28).

\%: Hind wing not extending beyond tip of fore wing. Lobe between gonangulum and subgenital plate vestigial to moderately developed (figs. 15-19).

Variation. - Throughout most of its range this species shows little variation. The apex of the male cercus varies in width (figs. 48, 50) but the general shape of the beak-shaped tip of the lamelliform margin is fairly constant (figs. 45-50). Also the lobe between the gonangulum and the subgenital plate of the female is invariably vestigial (figs. 15-17).

The material from the Pelopónnisos, however, presents a considerable clinal variation. In the male the beak-shaped tip of the cercus is apparently longer and more slender, the minute teeth of the lamelliform margin are situated more ventrally, and the apical incurvation of the cercus is slightly stronger. This variation is shown in figs. 35-37 and 51.55 which were made from material collected at localities ranging from the northwest to the southeast of the Pelopónnisos.

Similarly the females from these localities differ from the typical specimens of Acrometopa macropoda in having a moderately developed lobe between the gonangulum and the subgenital plate 
(figs. 18-19), although the size of the lobe does not attain that seen in Acrometopa servillea.

Distribution. - The range of the species covers Istra, the Adriatic coastal areas of Yugoslavia and Albania, the Gargano area of Italy, the Ionian islands and the western part of Greece and the Pelopónnisos eastward as far as a line indicated by the highest regions of the Pindhos range and farther southeastward in about the same direction, reaching the island of Kithira (distribution map).

Remarks. - With the aid of the illustrations of the cercus both typical and atypical males of Acrometopa macropoda are easily distinguished. The same applies to atypical females. However, the female in its typical form cannot be properly distinguished from females of Acrometopa italica or Acrometopa syriaca.

The type-material of Phaneroptera macropoda could not be traced, neither in the Institut für Pflanzenschutzforschung (formerly Deutsches Entomologisches Institut), Eberswalde (in litt. 15.III. 1977), nor in the Burmeister collection, preserved in the Zoological Department of the MartinLuther-Universität, Halle-Wittenberg (M. Dohrn, in litt. 14.X.1977). The specimen may be considered lost, and designation of a neotype (pl. I fig. 1) was necessary. The type-locality, Dalmatia, is restricted here to Kotor (= Cattaro), a town which was part of Dalmatia at the time of Burmeister. The measurements of the $\delta$ neotype are (lengths in $\mathrm{mm}$ ): body 24.0; pronotum 5.8; fore wing 36.0; hind wing 40.0; hind femur 30.2.

Since Fischer (1854) Phaneroptera dalmatina Serville, 1839, has been considered a synonym of Acrometopa macropoda. This synonymy is questionable, however, because both Acrometopa macropoda and Acrometopa italica have been recorded from Dalmatia, the type-locality of Serville's species. Unfortunately, the matter cannot be settled because the Serville's type-material is presumably lost (M. Descamps, in litt. 7.II.1977).

Previous records of Acrometopa macropoda as understood here were given under various names: Acrometopa macropoda, Acrometopa servillea and Acrometopa italica. A particular case to be mentioned is Beî-Bienko (1954), who based his description of Acrometopa servillea on four specimens, $2 \hat{\delta}$ and 1 o from Kithira and $1 \hat{\delta}$ from Kérkira. The Kíthira material had been identified as Acrometopa servillea by Brunner von Wattenwyl, and apparently on account of similarity BeîBienko considered the Kérkira male conspecific with the Kithira material. His comments upon this material are correct, and agree completely with the material from both localities at hand (figs. 48-49, 55). Presumably for similar reasons Čjchan (1963) assigned his Albanian material to Acrometopa servillea.

\section{Acrometopa servillea (Brullé, 1832)}

(figs. 10-11, 20-23, 29, 38-40, 56-61, pl. I fig. 2, map)

Phaneroptera servillea Brullé, 1832: 86, pl. 30 fig. 1.

Acrometopa servillea; Brunner von Wattenwyl, 1878: 86; 1882: 290, fig. 65 (both partim); Werner, 1902: 117 (partim); Burr, 1916: 193 (as A. macropoda); Berland \& Chopard, 1922: 167; Burr, Campbell \& Uvarov, 1923: 126, 150; Ramme, 1927: 122, figs. 5c-8c, 9, pl. 5 fig. 5a; Werner, 1933a: 400; 1934: 323; 1937a: 145 (partim); 1937b: 106, figs. 5-6, 1938: 166; Kaltenbach, 1965: 471.

Acrometopa cretensis; Werner, 1937b: 108 (partim).

Material studied. - Neotype of labelled: Hellas (Pelop.: Korinthia) Sofikon ( $3 \mathrm{~km} \mathrm{~N}) 300 \mathrm{~m} \mathrm{6.VII.1974} \mathrm{F.} \mathrm{Willemse}$ c.s. (ZMA).

Greece: Korinthía: (1) Mt. Killíni, Áno Tríkkala, 1 ô, 2 우 (CW); $1150 \mathrm{~m}$, 17.VIII.1973, La Greca, 1 ô (IBA); (2) Lávka, $3 \mathrm{~km} \mathrm{E,} 1$ ô; (3) Sofikón, $3 \mathrm{~km} \mathrm{~N}, 1$ ô, 1 q; Argolís: (4) Skotiní, Mt. Olíyirtos, $1 \hat{\delta}, 1$; (5) Ligourión, $4 \mathrm{~km} \mathrm{~W}, 1$ \%; (6) Áyios Eléni, SE of Epidhavros, 1 ô (all CW); Attikí: (7) Aíyina (= Aegina), 13.V.1937, Acrometopa servillea Brullé det. Werner, 1 ô; (8) Athínai (= Athens), Heldreich, coll. Br. v. W., Acrometopa servillea Brullé det. Br. v. W., 1 ô, 1 क (all NMW); (9) Mt. Párnis, 1 \& ; Fthiótis: (10) Melidhóni, W of Arkítsa, 1 \% (11) Oíti village, 2 tิ, 7 우 (all CW); Tríkkala: (12) Tírna, $1300 \mathrm{~m}$, 4.VIII.1973, La Greca, 1 ô, 2 f (IBA); (13) Khrisomiléa, 1 î 2 q̊; (14) Mourikáni, 2 q; (15) Trigón, 1 ô, 1 + (all CW); (16) Kalambáka, 5.VIII.1973, La Greca, 1 \& (IBA); Ioánnina: (17) Ármata, $1 \hat{\delta}, 1$ \&; Magnisía: (18) Glafirá, 1 ş; (19) Khoreftón, 1 \&; Lárisa: (20) Dhímitra-Anatóli, 1 î, 1 \%; (21) Elassón, $4 \mathrm{~km} \mathrm{~W}$, 1 ô, 1 q; Grevená: (22a) Dheskatí, 5-10 km E, 1 ô; (22b) Paraskeví, 1 ô, 4 \&; Kozáni: (23) Sérvia, 2 ô; (24) Velvendós, 1 ô; Piéria: (25) Litókhoron, 9 ô, 1 q; Kilkís: (26) Plataniá, 1 ô; (27) Evzonoi, 7 ô, 2 \& (all CW); Thessaloníki: (28) Lembet, $6 \mathrm{~km} \mathrm{~N}$ of Thessaloniki, VI.1916, M. Burr, 1 ô (BMNH); Khalkidhikí: (29) Yerakiní, 1 \% (CW); Dráma: (30) Dráma, 3.VI.1964, 1 ô ; Kaválla: (31a) Kaválla, 21, (31b) Bátis, 30.VI.1963, 1 ô, 1 \% Thásos: (32a) Liménos, 15.VI.1962, 1 ㅇ (all Kaltenbach, Acrometopa servillea Brullé det. A. Kaltenbach, NMW); (32b) Prinos, 21.VII.1963, S. Daan \& V. van Laar, 


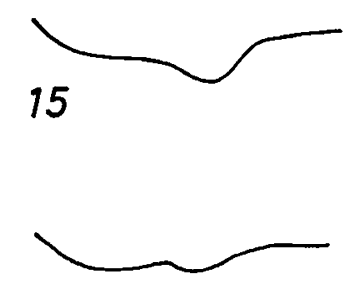

16

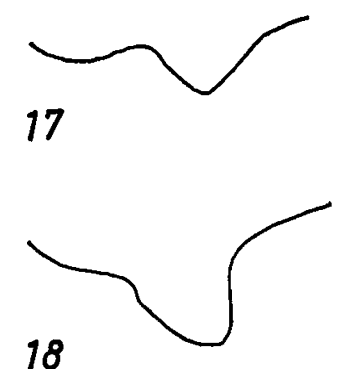

18
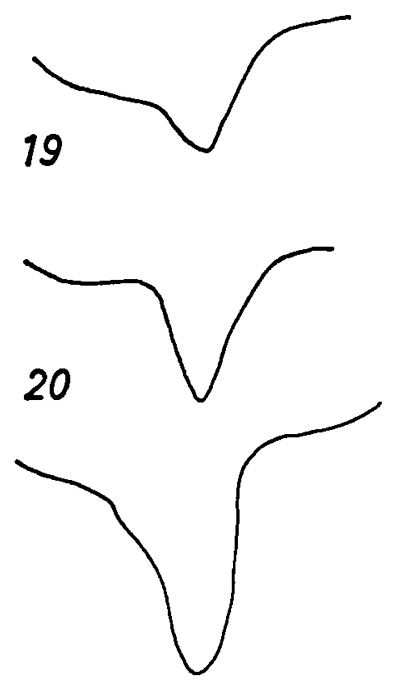

21

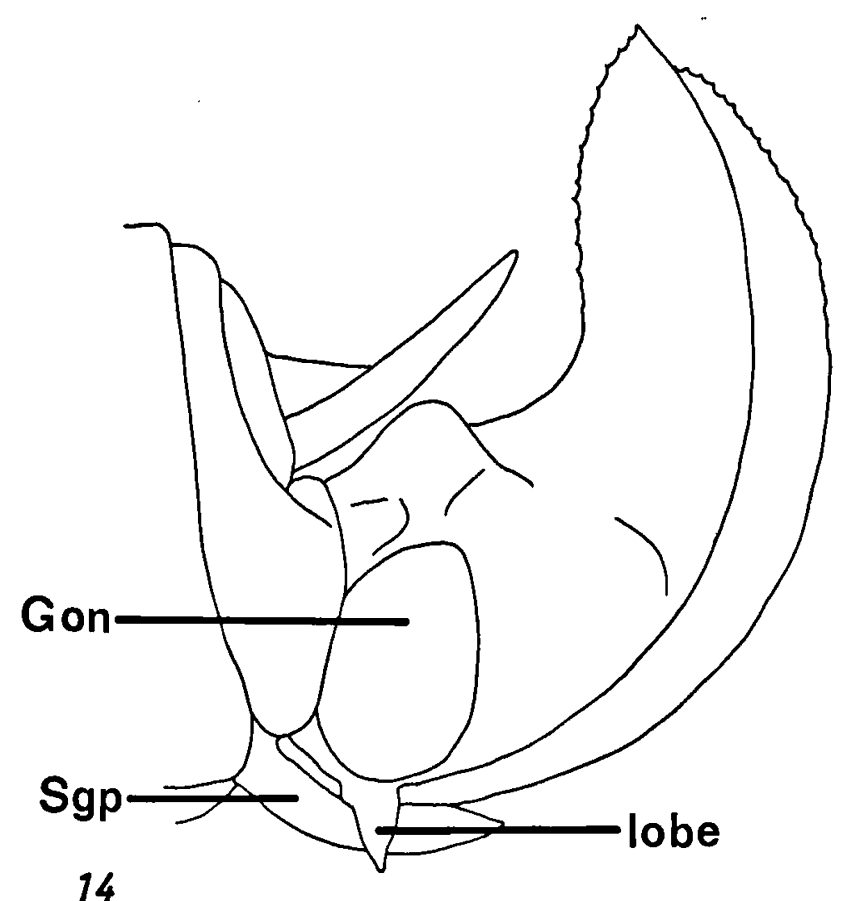

14
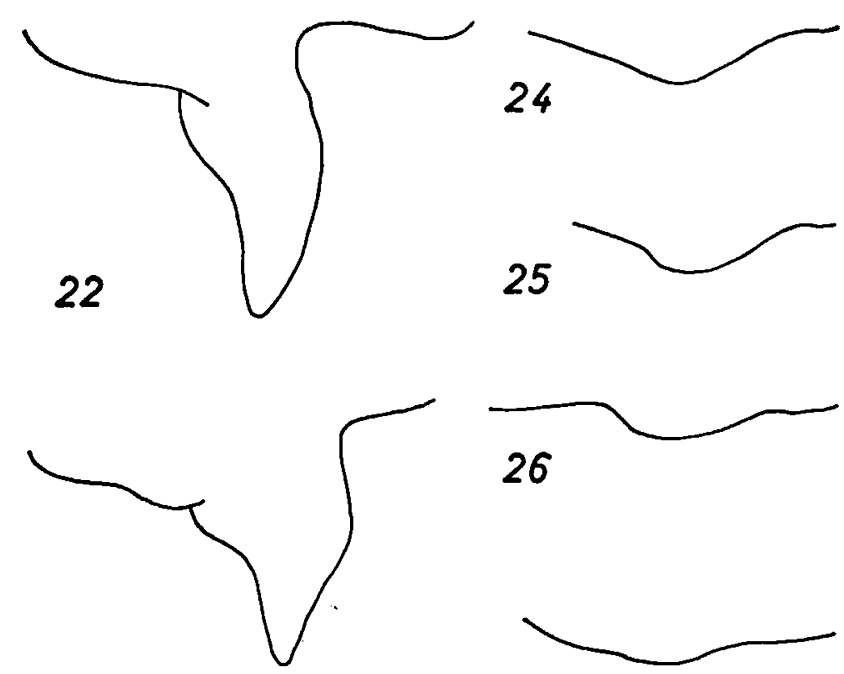

23

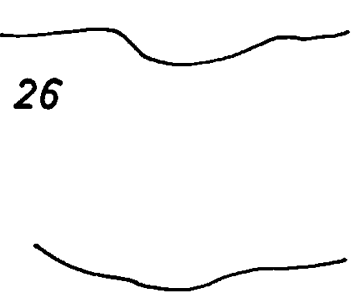

27

Figs. 14-27. Upper margin of lower ovipositor valve in Acrometopa: 14, left side of abdominal terminalia of Acrometopa servillea (Brullé) (Magnisía, Khoteftón), lobe between gonangulum (Gon) and subgenital plate (Sgp), as indicated, refers to figs. 15-27: 15-19, A. macropoda (Burmeister) (15, Istra, Učka; 16, Ioánnina, Kalpákion; 17, Akhaía, Kalávrita; 18, Voíotia, Mt. Parnassós, CW; 19, Arkadhía, Tripolis); 20-23, A. servillea (Brullé) (20, Korinthía, Mt. Killíni; 21, Argolis, Skotiní; 22, Fthíotis, Oíti; Tríkkala, Trígon); 24-25, A. italica Ramme (24, Sicilia, paratype; 25, Italy, Sperlonga); 26, A. syriaca Brunner von Wattenwyl (Piéria, Litókhoron); 27, A. cretensis cretensis Ramme (Kríti, Linoséli).

2 ô (ZMA); Lésvos: (33) Áyios Evstrátios (- Agiostrati), 5.VII.1936, F. Werner, Acrometopa servillea Brullé det. Werner, 1 ô, 2 \%; Khíos: (34) Khios (= Chios) ,30.VI. 1936, F. Werner, Acrometopa servillea Brullé det. Werner, 2 ô, 1 \% (both NMW), 11.VI.1934, 1 \& (BMNH);
Kikládhes: (35) Kéa, 2.VI.1936, F. Werner, Acrometopa cretensis Ramme det. Werner, 2 ô (NMW).

Anatolia: Izmir (- Smyrna) Br. v. W., 5943, Acrometopa syriaca $\mathrm{Br}$. det. Br. v. W., 1 \% (cotype of Acrometopa syriaca Brunner von Wattenwyl, NMW). 


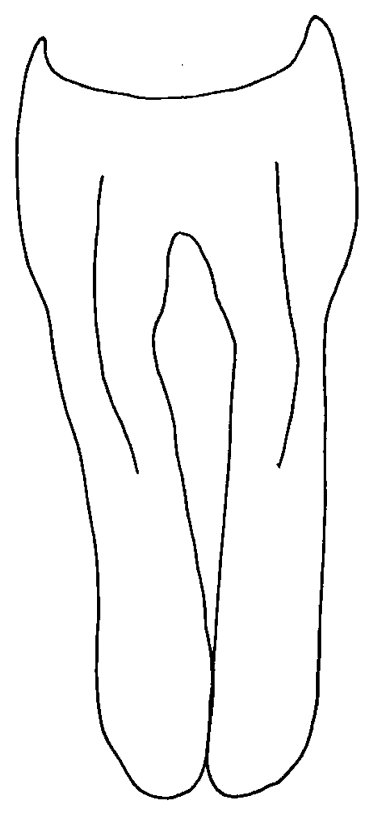

28

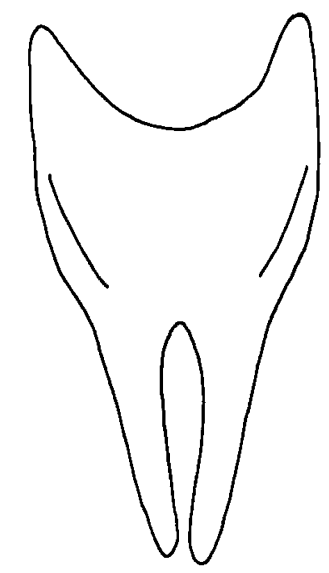

31

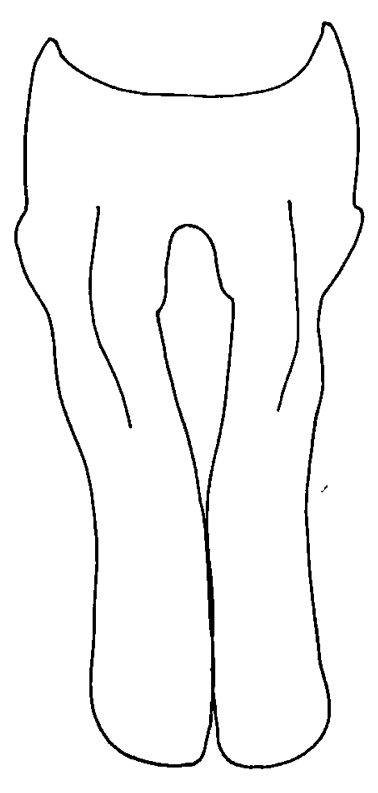

29

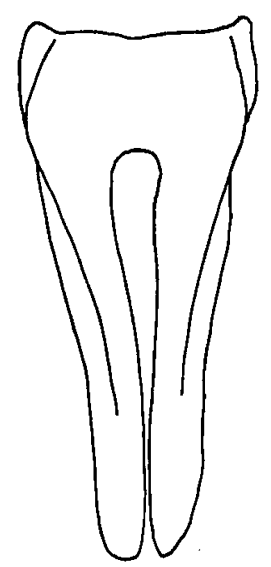

32
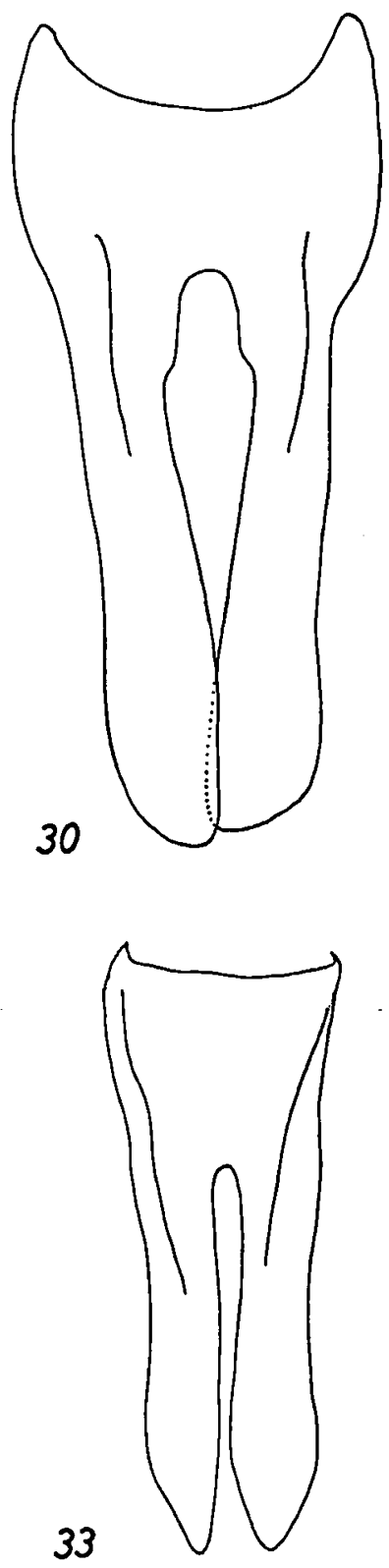

Figs. 28-33. Male subgenital plate in Acrometopa, ventral view: 28, A. macropoda (Burmeister) (Crna Gora, Krstač); 29, A. servillea (Brullé) (Piéria, Litókhoron); 30, A. italica Ramme (Sicilia, paratype); 31, A. syriaca Brunner von Wattenwyl (Piéria, Litókhoron); 32, A. cretensis cretensis Ramme (Krití, Mállia); 33, A. cretensis daedali ssp. n. (paratype).

Diagnosis. - $\delta$ : Stridulatory file as in the typespecies of the genus. Cercus apically strongly incurved (figs. 38-40); apex strongly excavate, lamelliform margin terminating into a beak-shaped process, which is as long as or, usually, longer than the greatest width of the apex of the cercus (figs.
56-61). Lobes of subgenital plate parallel-sided (fig. 29).

\&: Hind wing not extending beyond tip of fore wing. Between subgenital plate and gonangulum a well developed, roughly triangular projecting lobe arising from upper margin of lower valve of ovipositor (figs. 20-23). 
Variation. - The amount of variation within this species is slight, but the differences found in the specimens from Mt. Killini deserve to be mentioned. In that material the beak-shaped tip of the male cercus is slightly shorter (figs. 38, 56) and the lobe between the gonangulum and the subgenital plate of the female is apparently smaller than usual (fig. 20).

Distribution. - The range of the species covers Turkey, the central and northern Aegean islands, the northern and eastern parts of the Greek mainland, reaching westward as far as the eastern slopes of the Pindhos range and extending southward from Mt. Oiti into the extreme eastern part of the Pelopónnisos and some neighbouring islands as far south as the island of Kéa (distribution map).

Remarks. - Both the male and the female of this species are well characterized. Confusion is possible only with atypical forms of Acrometopa macropoda, in which case reference should be made to the illustrations given.

The type of Phaneroptera servillea Brulle could not be traced (M. Descamps, in litt. 23.VIII. 1976) and is presumably lost. The original publication refers to a male from the Pelopónnisos without precise locality. However, by far the largest part of that peninsula is occupied by Acrometopa macropoda. For these reasons a neotype is designated, a male from Sofikón in the eastern Pelopónnisos (pl. I fig. 2). Its measurements (length in $\mathrm{mm}$ ) are as follows: body 26.5; pronotum 5.8; fore wing 35.0; hind wing 40.0; hind femur 32.1 .

In literature records under the name of Acrometopa servillea from Greece are numerous. Some of these are referred now to Acrometopa syriaca, the record from Kriti to the nominate subspecies of Acrometopa cretensis, and several others to Acrometopa macropoda. The material from the island of Kéa (Kikládhes) recorded by Werner (1937b) under Acrometopa cretensis has been re-examined. It belongs partly to that species and partly to Acrometopa servillea.
Acrometopa italica Ramme, 1927

(figs. 24-25, 30, 41, 62-64)

Acrometopa macropoda italica Ramme, 1927: 121, figs. 5a-8a, 9.

Acrometopa italica; Uvarov, 1935: 75; La Greca, 1959: 102, fig. 113.

Material studied. - Paratypes labelled: Sicilia, Messina am Colle S. Rizzo, 2-400 m, 27.VII.1924, Ramme-Richter, 1 ô, 1 (NMM), 1 \% (BMNH).

Sicilia: Portelli Mandrazzi (Peloritani), $1000 \mathrm{~m}, 23$. VII. 1961, La Greca, 1 ô (ZMA); Vizzini (Catania), 28.VI. 1969, Nobile, 1 \% (ZMA); Randazzo, 800 m (Etna), 3.VII.1969, Marcellino \& Ronsisvalle, 1 f, 1 \& (IBA).

Italy: Sperlonga (Terracina, Latina), 29.VI.1959, La Greca, 1 o, 1 क (IBA), 1 ô, 1 \& (CW); Puglia, RuvoGravina, 300 m, 5.VII.1977, F. \& L. Willemse, 3 to, 3 ㅇ (CW); Liguria, Pegli, 21.VIII. 1917, ex Malc. Burr coll., 1 ô, 1 q (BMNH), 2 ô, 1 क (HMO).

Corse: Asco, $620 \mathrm{~m}, 24 . \mathrm{VII} .1953, \mathrm{H}$. Wiering, 1 के (ZMA).

Dalmatia: Dalmatie Brunner de Wat., ex coll. M. Burr, 1 s, 1 \& (HMO).

Diagnosis. - $\delta$ : Stridulatory file as in typespecies of the genus. Cercus slightly incurved in apical fourth (fig. 41); apex narrow and slightly excavate, lamelliform margin without a beakshaped terminal process but simply dentate (figs. 62-64). Lobes of subgenital plate parallel-sided (fig. 30).

†: Hind wing not extending beyond tip of fore wing. Lobe between gonangulum and subgenital plate vestigial (figs. 24-25).

Variation. - Not noticeable.

Distribution. - The range of the species covers Corse, Sardegna, Sicilia, continental Italy excluding the extreme northern part and the high mountains, and ? Dalmatia.

Remarks. - As was pointed out above in the discussion of the specific characters within the genus, the difference between $A$. italica and $A$. macropoda appears to concern the male cercus only.

Uvarov (1935) wrote that the distributional areas of $A$. macropoda and $A$. italica overlap in Dalmatia. His Dalmatian material has been reexamined and his identifications have proved to be correct. The record of $A$. italica from Dalmatia, however, has not been confirmed since. 

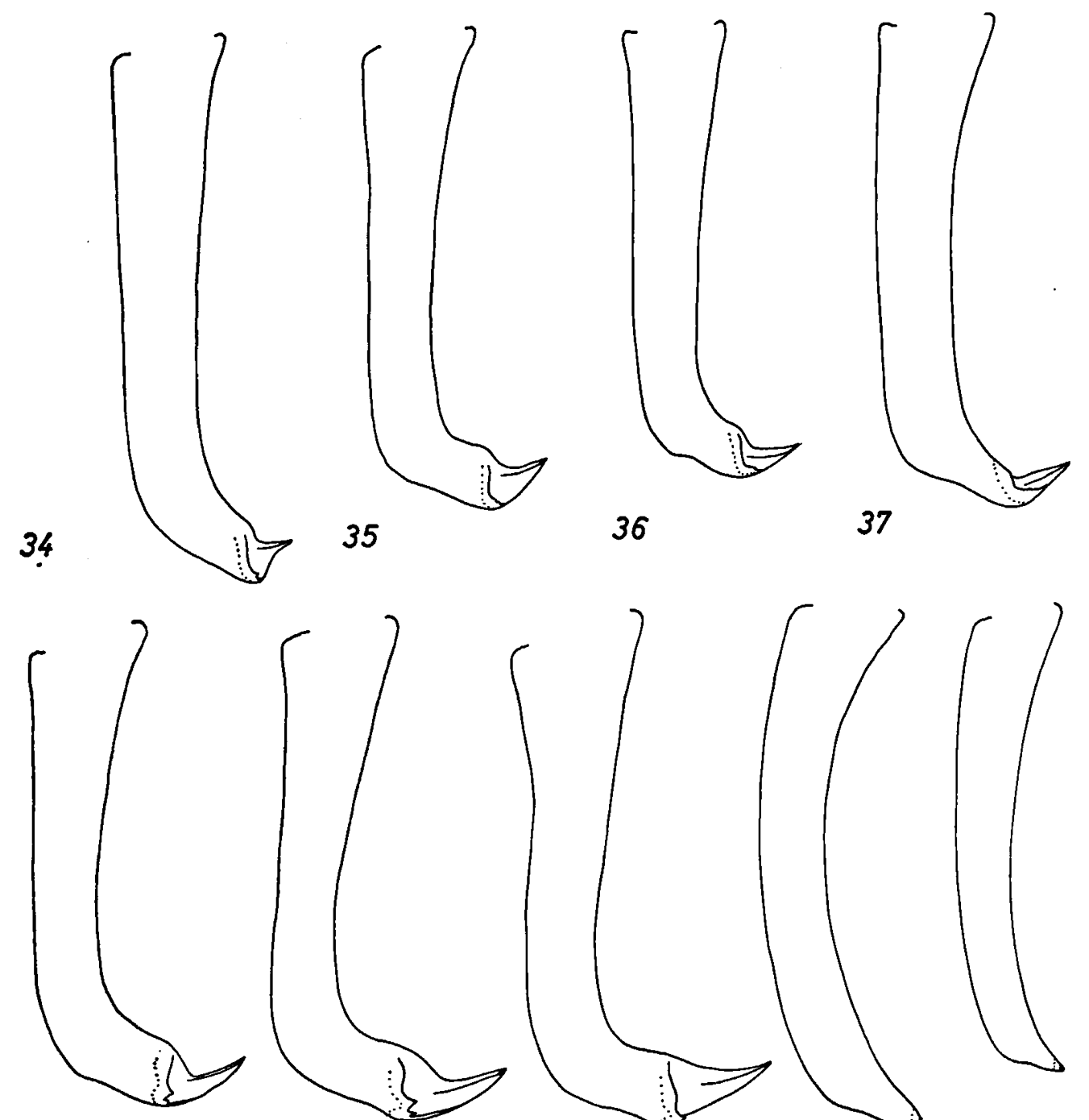

38

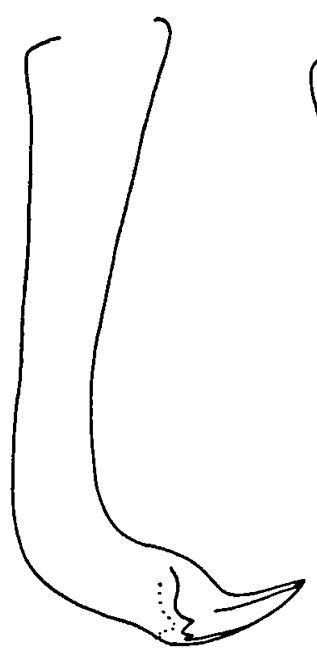

39
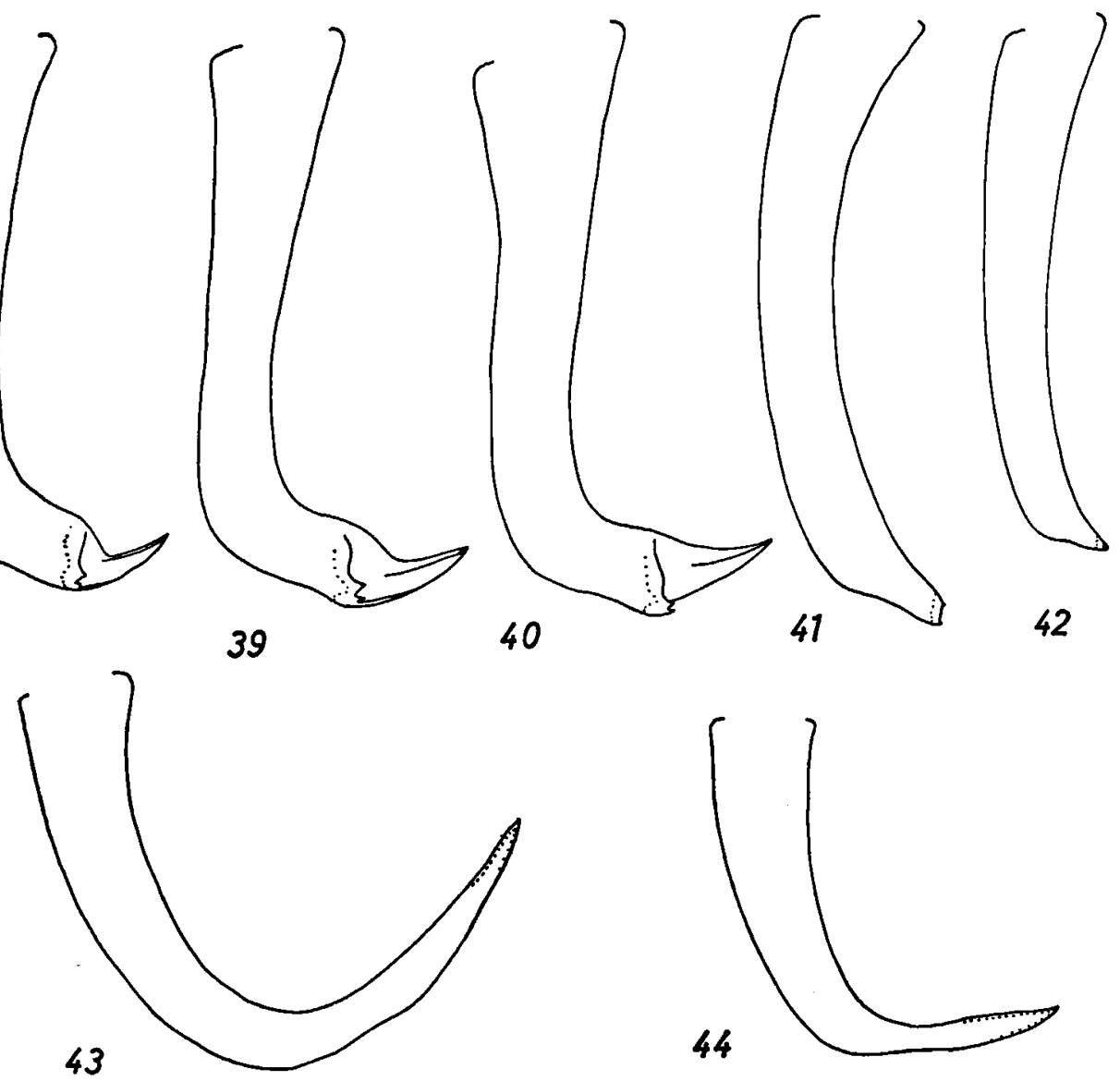

Figs. 34.44. Left male cercus in Acrometopa, dorsal view: 34-37, A. macropoda (Burmeister) (34, Istra, Valtura; 35, Voíotia, Mt. Parnassós, CW; 36, Argolís, Akhladhókambos; 37, Kíthira, Werner); 38-40, A. servillea (Brullé) (38, Korinthía, Mt. Killíni; 39, Fthiotis, Oíti; 40, Thásos, Prínos); 41, A. italica Ramme (Italy, Sperlonga); 42, $A$. syriaca Brunner von Wattenwyl (Piéria, Litókhoron); 43, A. cretensis cretensis Ramme (Kríti, Mállia); 44, A. cretensis daedali ssp. n. (paratype). 
Acrometopa syriaca Brunner von Wattenwyl, 1878

(figs. 6-9, 26, 31, 42, 65-66, pl. I fig. 3, map)

Acrometopa syriaca Brunner von Wattenwyl, 1878: 87; Werner, 1901: 289; Ramme, 1927: 122, figs. 5d-8d, 9; Werner, 1933b: 189 (?); 1936: 10; Ramme, 1939: 51; Beî-Bienko, 1954: 124; Kaltenbach, 1967: 191; Willemse, 1977: 52.

Acrometopa syriaca (?); Werner, 1933a: 400 (partim?). Acrometopa festae Giglio-Tos, 1893: 13, pl. fig. 3; Ramme, 1927: 122; Werner, 1933b: 189.

Acrometopa elsae Werner, 1937b: 107, fig. 7; Ramme, 1939: 51.

Acrometopa macropoda; Werner, 1933b: 189.

Acrometopa macropoda macropoda: Salfi, 1929: 213; Jannone, 1936: 145, fig. 23; Salfi, 1937: 4.

Acrometopa sp.; Burr, Campbell \& Uvarov, 1923: 127 (?).

Material studied. - Type-series of Acrometopa syriaca, labelled: Coll. Br. v. W. ex coll. Lederer Beirut, 8158, det. Br. v. W. Acrometopa syriaca Br., 1 ô (lectotype); Coll. Br. v. W. Aidin, 5906, Acrometopa syriaca Br. det. Br. v. W., 1 ô (paralectotype); Smyrna Br. v. W., 5943, det. Br. v. W. Acrometopa syriaca Br., 1 \% (paralectotype) (all NMW).

Type-series of Acrometopa elsae: (6) Sámos, Vathi (= Vathy), 2.VI.1936, F. Werner, Acrometopa elsae Wern. Type $\hat{\delta}$ det. Werner, Acrometopa syriaca Br. det. Ramme, 1 ô (holotype); (7) Sámos, Marathókambos (= Marathokampos), 24.VI.1936, F. Werner, Acrometopa elsae Wern: cotype $q$ det. Werner, Acrometopa syriaca Br. det. Ramme, 1 o (paratype) (both NMW).

Greece: Piéria: (1) Litókhoron, Hotel Lito, 19 ŝ, 1 \& (CW); (2) Kolindrós, $10 \mathrm{~km} \mathrm{W,} \mathrm{24-26.VII.1965,} \mathrm{Blom-}$ mers e.a., 1 ô (ZMA); Evros: (3) Tukherón, 2 \& (CW); (4) Samóthraki, Therme S.L., 15.VIII.1962, Guichard \& Harvey, 1 (BMNH); Lésvos: (5) Mitilíni (= Mytilene) Br. v. W., Acrometopa syriaca Br. det. Br. v. W., $1 \hat{\jmath}$, 1 o (NMW); Sámos: (6) Koútsi \& Khóra \& Koumaradhaioi, 25-27.VI.1977, M. C. \& G. Kruseman, 2 ô, 5 웅 (ZMA); Dhodhekánisos: (8) Kós, Antimákhia (= Antimachia), 7.VI.1935, O. Wettstein, Acrometopa syriaca Br. det. Werner, 1 juv. ô ; (9) Ródhos, Rodhíni ( $=$ Rhodos, Rodini), 23 \& 24.VI.1966, Kaltenbach, Acrometopa syriaca Br. v. W. det. Ka!tenbach, 1 \&, 1 \%; (10) Kárpathos, Voládha, 15-18.VI.1935, O. Wettstein, Acrometopa syriaca det. Werner, 1 \& (all NMW).

Cyprus: Ballapais, $6 \mathrm{~km} \mathrm{SE}$ of Kyrenia, 200-240 m, 10. VI.1971, 1 \&; E of Kyrenia, 11.VI.1971, both M. J. \& J. P. Duffels, 2 o, 1 \& (all ZMA).

Israel: Tiberias, 18-27.V.1967, C. A. W. Jeekel, 6 \&, 1 ㅇ (ZMA).

Diagnosis. - ô: Stridulatory file without elevations and alternating depressions (figs. 8-9). Size of stridulatory organ larger than in type-species. Cercus slightly incurved apically (fig. 42); apex narrow, not excavate but with a pair of minute and solid teeth (figs. 65-66). Subgenital plate with lobes distinctly narrowing apically (fig. 31). Apical parts of antennae annulated.

: Hind wing not extending beyond tip of fore wing. Lobe between gonangulum and subgenital plate vestigial (fig. 26). Colouration as in male.

Variation. - Not noticeable.

Distribution. - The range of the species extends from Egypt, through Israel, Lebanon and Syria into Iraq and Anatolia, reaching westward to Cyprus, the islands of the eastern part of the Aegean Sea and the Greek part of Thraki and Makedhonía (distribution map).

Remarks. - The species is well characterized by the structure of the stridulatory file and the abdominal terminalia of the male. The female, however, may be confused with females of $A$. macropoda and $A$. italica. The colouration of the antennae may be helpful, but in preserved material these parts are usually broken off.

The lectotype of Acrometopa syriaca from Beirut (Pl. I fig. 3) has the following measurements (length in $\mathrm{mm}$ ): body 21.0; pronotum 5.7; fore wing $35.0 \mathrm{~mm}$; hind wing 40.0 ; hind femur 34.5. This male is conspecific with the female paralectotype from Aidin. The other female of the original type-series, from Izmir (= Smyrna), belongs to Acrometopa servillea.

Ramme (1927) and Werner (1933b) considered Acrometopa festae Giglio-Tos, 1893, synonymous with Acrometopa syriaca, and their opinion is followed here. The type material of Acrometopa festae could not be traced.

The synonymy of Acrometopa elsae Werner, 1937, with Acrometopa syriaca, which was established by Ramme (1939) could be confirmed by the actual examination of the type-specimens.

Most of the previous records of Acrometopa syriaca in literature seem reliable, but some are in need of confirmation, viz. Límnos (= Lemnos) (Werner, 1933a) and Khíos (= Chios) (Werner 1933b).

Literature records of Acrometopa macropoda from the eastern Aegean islands refer to female specimens only, except for one record from Ródhos (Salfi, 1937). Since females of Acro- 


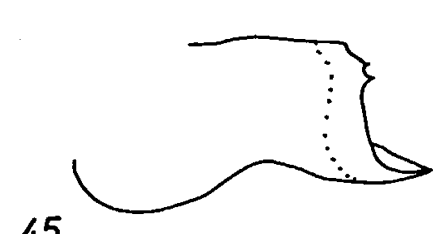

45

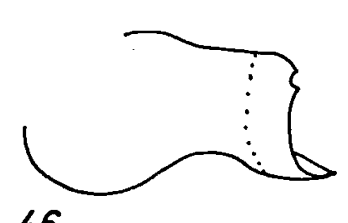

46
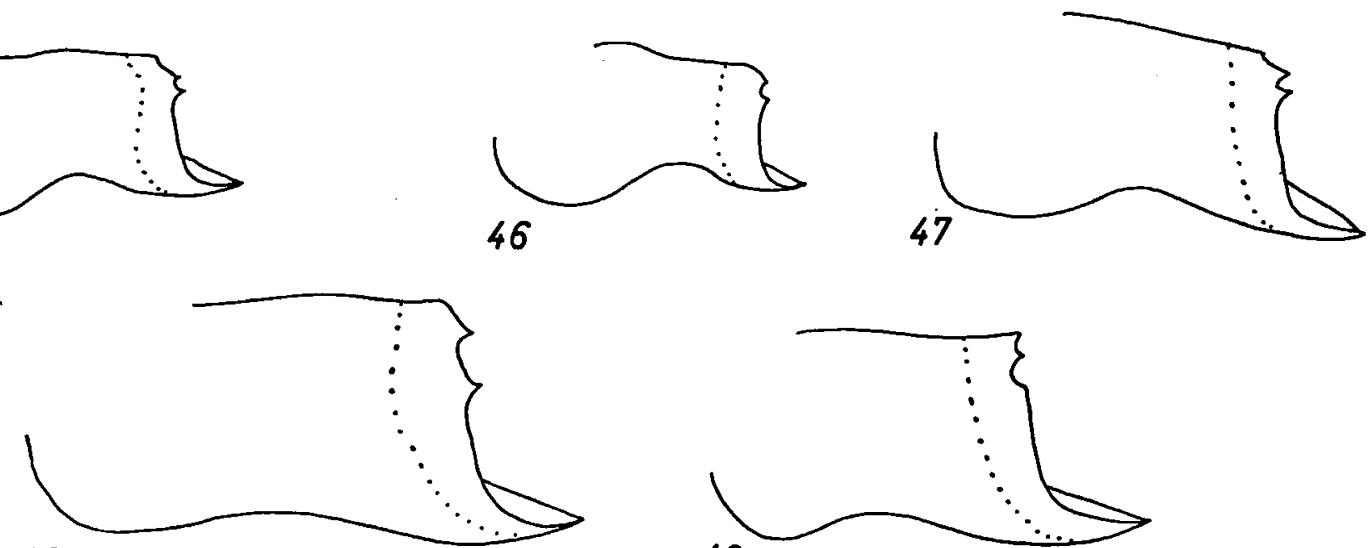

48

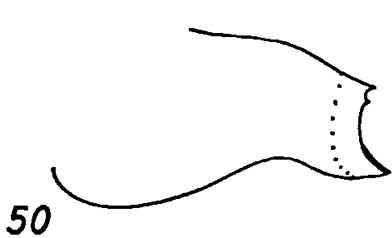

50

51
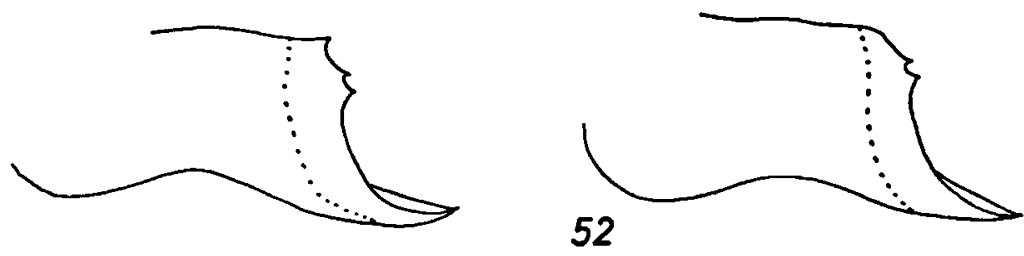

53
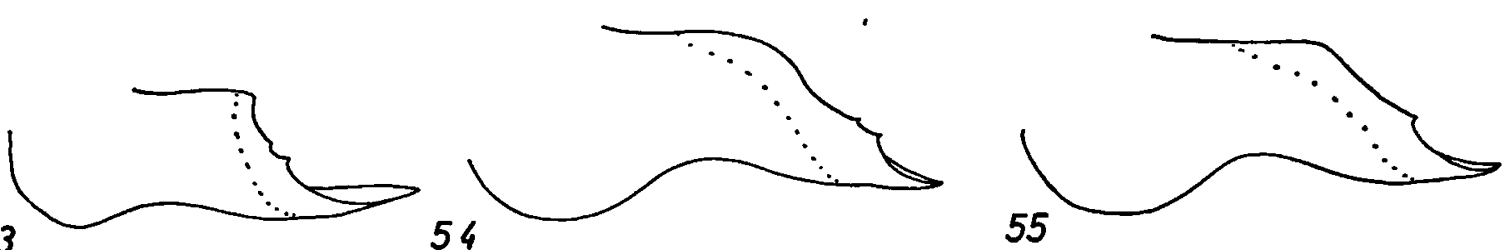

Figs. 45-55. Apex of male cercus in Acrometopa macropoda (Burmeister), posterior view (45, Istra, Valtura; 46, Crna Gora, neotype; 47, Ioánnina, Sarandáporos; 48, Kérkira, Pa tália; 49, Kérkira, Gazátika; 50, Ãrta, Ramía - Livádhion; 51, Voíotia, Mt. Parnassós, CW; 52, Arkadhía, Trípolis; 53, Argolís, Akhladhókambos; 54, Lakonía, Monemvasia; 55, Kíthira, Werner).

metopa macropoda and Acrometopa syriaca are indistinguishable, and the eastern Aegean islands are lying far outside the range of Acrometopa macropoda, these records are assigned now to Acrometopa syriaca. The record from Ródhos refers to a single male specimen which was probably misidentified.

\section{Acrometopa cretensis Ramme, 1927}

This species, which occurs in Kriti, the western Kikládhes and Ikaría, is well characterized by the shape of the male stridulatory file (figs. 12-13). Whereas the material from Kríti and the Kikládhes agrees completely with the original descrip- tion, that from Ikaria differs clearly in the shape of the male cercus, and is described below as a new subspecies.

Acrometopa cretensis cretensis Ramme, 1927 (figs. 27, 32, 43, map)

Acrometopa macropoda; Kuthy, 1907: 553. Acrometopa servillea; Werner, 1927: 428 (partim).

Acrometopa cretensis Ramme, 1927: 122, figs. Se-8e, 9, pl. 5 figs. Sb-c; Werner, 1934: 322; 1937b: 108 (partim); Willemse \& Kruseman, 1976: 125.

Material studied. - Kríti: Iráklion: (1) Stalis, $5 \mathrm{~km} \mathrm{NE}$ Mállia, 4-20.VI.1970, Manoil, 1 ô (NMW); (2) Mállia, 9.VI.1972, 1 ô ; (3) Phaistós, 18.VI.1972, 1 \& (both M. C. \& G. Kruseman, ZMA); Khanía: (4) Lévka Mts., Linoséli above Xilóskalo, $1300 \mathrm{~m}, 1$ \& (CW). 

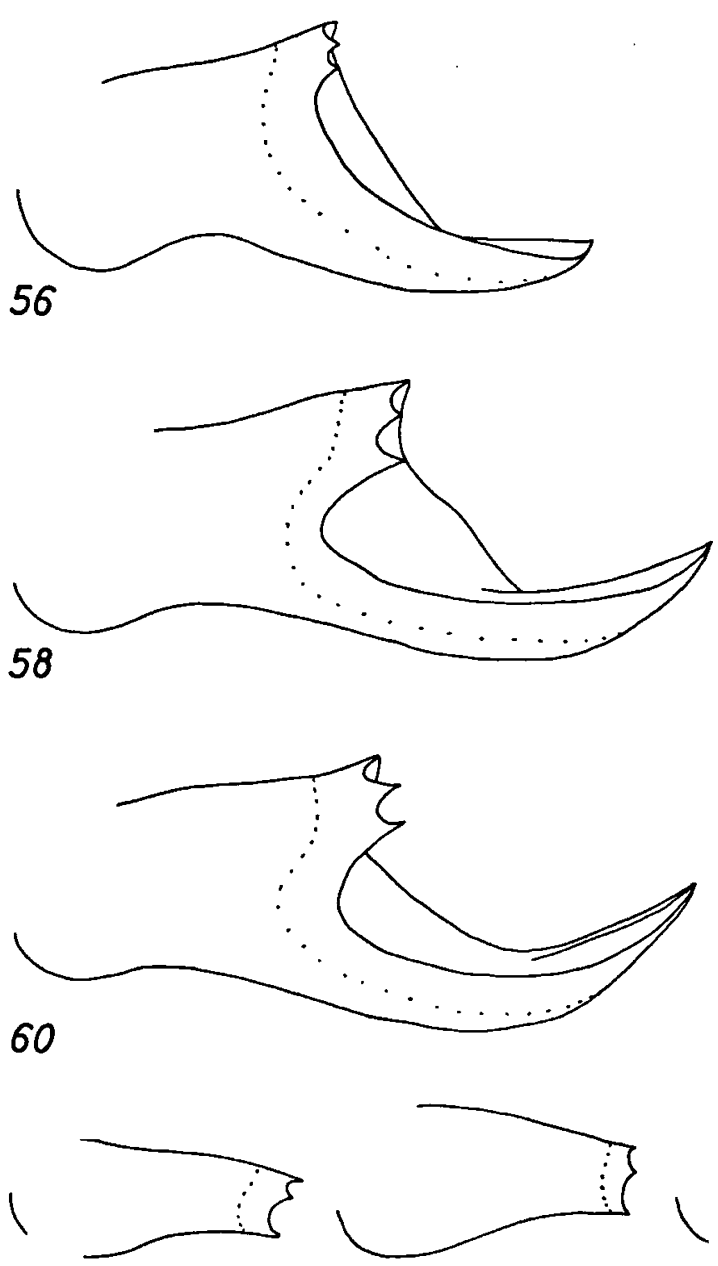

62

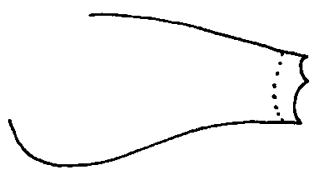

63
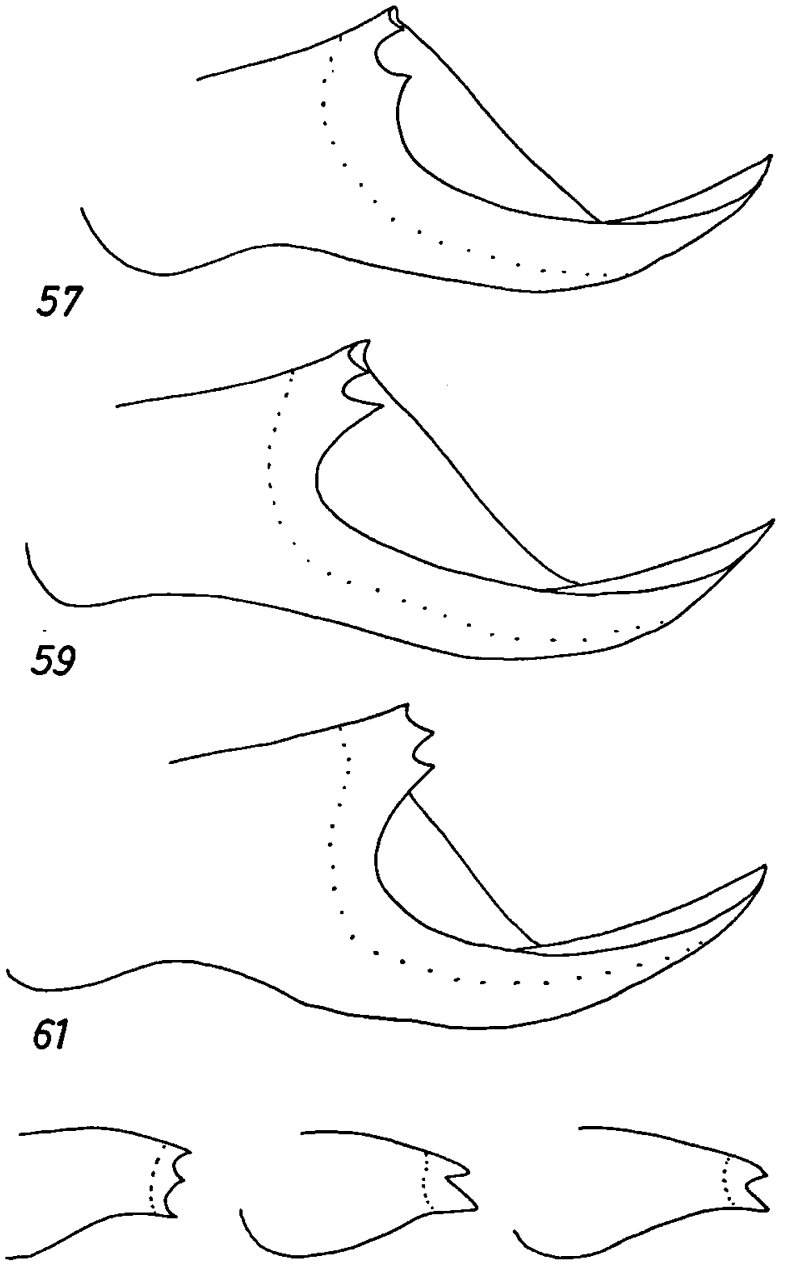

65

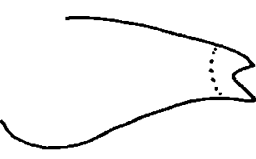

66

Figs. 56-66. Apex of male cercus in Acrometopa, posterior view: 56-61, A. servillea (Brullé) (56, Korinthía, Mt. Killini; 57, Korinthía, Lávka; 58, Korinthía, Sofikón, neotype; 59, Kilkís, Evzonoi; 60, Thásos, Prínos; 61, Khíos, Werner); 62-64, A. italica Ramme (62, Sicilia, paratype; 63, Italy, Sperlenga; 64, Corse); 65-66, A. syriaca Brunner von Wattenwyl (65, Piéria, Litókhoron; 66, Israel, Tiberias).

Kikládhes: (5) Kéa, 7.VI.1936, F. Werner, Acrometopa cretensis Rme det. Werner, 1 ô, 1 o (NMW); (6) Kímolos, 3.VI.1934, Werner, 1 of, 1 \% (NMW), 1 ô (BMNH); (7) Polívos, 6.VI.1934, Acrometopa cretensis Rme det. Werner, 1 of (NMW).

Diagnosis. - ô: Stridulatory file with three sinuate elevations alternating with depressions (figs. 12-13). Cercus slender, strongly and evenly incurved all over its length, apex pointed with a fine longitudinal crest (fig. 43). Subgenital plate with the lobes distinctly narrowing apically (fig. 32).

$\$$ : Hind wing extending beyond tip of fore wing. Lobe between gonangulum and subgenital plate vestigial (fig. 27).

Variation. - The smaller measurements of the Kriti material are not considered of specific importance since the measurements of the Kikládhes specimens are approaching those of the other species of the genus.

Distribution. - As far as known the range of the nominate subspecies of Acrometopa cretensis includes only Kriti and the western Kikládhes (distribution map). 
Remarks. - Both sexes of this species are well defined.

Previous records of this species for the islands of los, Kíthnos, Andipáros and Sífnos (Werner, 1934) are not indicated on the distribution map, since they were based either on observations or on juvenile specimens.

Other previous records (Ramme, 1927), however, are indicated on the map and numbered as follows: Kríti: (8) Piskokéfalo; (9) Khamaízi; (10) Amári; (11) Rodhopoú.

Acrometopa cretensis daedali subsp. nov.

(figs. 12-13, 33, 44, Pl. I fig. 4, map)

Material studied. - Hellas, Ikaria, Therma, 14-21.VI.1977, M. C. \& G. Kruseman, of holotype, $q$ allotype, $15 \hat{o}$ paratypes, 5 q paratypes; Ikaria, Ayios Kirikos, 20.VI.1977, M. C. \& G. Kruseman, 1 ô paratype; 17.VI.1963, S. Daan \& V. van Laar, 3 o paratypes (all ZMA).

Diagnosis. - $\delta$ : Pl. I fig. 4. Differs from the nominate subspecies as follows. Cercus shorter, basal half more strongly tapering and, just beyond the middle of length abruptly and almost rectangularly incurved, slightly widening apically, tip pointed (fig. 44). Lobes of subgenital plate less narrowing apically (fig. 33).

: Similar to nominate subspecies.

Measurements (length in $\mathrm{mm}$ ): body of 24-27, o 28-29; pronotum of 5.5-5.9, $q$ 5.8-6.1; fore wing of 27-30, + 27-29; hind wing $\hat{o}$ 32-34, ㅇ 29-31; hind femur $\delta$ 29-32, $q$ 31-32.

Variation. - Not noticeable.

Distribution. - Known only from the Aegean island of Ikaría (distribution map).

Remarks. - The male is well-defined by the shape of the cercus. The female, however, cannot be distinguished from that of the nominate form.

Although the distinction between the two subspecies of $A$. cretensis concerns only a single character, the rate of difference and the importance of the character justify taxonomic recognition.

\section{ZOOGEOGRAPHY}

The recognition of three morphologically well defined groups of species within the genus Acrometopa, viz., (1) $A$. italica, $A$. macropoda and
A. servillea, (2) A. syriaca, and (3) A. cretensis cretensis and $A$. cretensis daedali, is supported by the distributional pattern of these groups. Since the geographical areas of $A$. servillea, $A$. syriaca and $A$. c. cretensis show a partial overlap the conclusion is that these species groups must be regarded as reproductively isolated taxa.

On the other hand, $A$. italica, $A$. macropoda and $A$. servillea apparently have an allopatric distribution (the record of $A$. italica from Dalmatia is considered doubtful). I have considered the possibility that $A$. italica, macropoda, and servillea are geographical races (subspecies) of one another. In my opinion, this is a boundary case, but since the morphological characters are sufficiently pronounced, I have retained for the moment a status as full species. Their geographical succession from the West to the East coincides with the structural changes in their characters. Although the distinction between the three taxa is rather easy, they seem to represent vicariant populations, and their reproductive isolation may not have been completed yet. This may be the reason of the morphological variation which occurs in a narrow zone where the areas of $A$. macropoda and $A$. servillea are in contact with each other. This zone reaches from Mt. Parnassós to the opposite part of the Pelopónnisos, through Arkadhía, southwestern Argolís, Lakonía and onto the island of Kithira (localities of $A$. macropoda numbered 22, 24-25, 29, 39-40, 46-48, of $A$. servillea numbered 1 ). No variation occurs in the Pindhós range, however, although $A$. servillea occurs on the eastern slopes and $A$. macropoda on the western. Possibly the Pindhós range constitutes a nearly complete barrier, due to the fact that the species of Acrometopa cannot survive at altitudes above $1500 \mathrm{~m}$.

\section{REFERENCES}

Bế-Bienko, G., 1954. Orthoptera 2, no. 2. Tettigonioidea. Phaneropterinae. Fauna U.S.S.R. (Zool. Inst. Akad. Nauk SSSR, Moscow), (n.s.) 59: 1-385, figs.

Berland, L. \& L. ChOPARD, 1922. Travaux scientifiques de l'Armée d'Orient (1916-1918). Orthoptères. Bull. Mus. natn. Hist. nat. Paris, 1922: 166-170, 230-235, figs.

BRullé, M. A., 1832. Insectes Orthoptères, in: Expédition scientifique de Morée, 3: 81-97, figs. (Levrault, Paris).

BRUNNER VON WATtENWYL, C., 1878. Monographie der Phaneropteriden: 1.401, figs. (Brockhaus, Wien). 


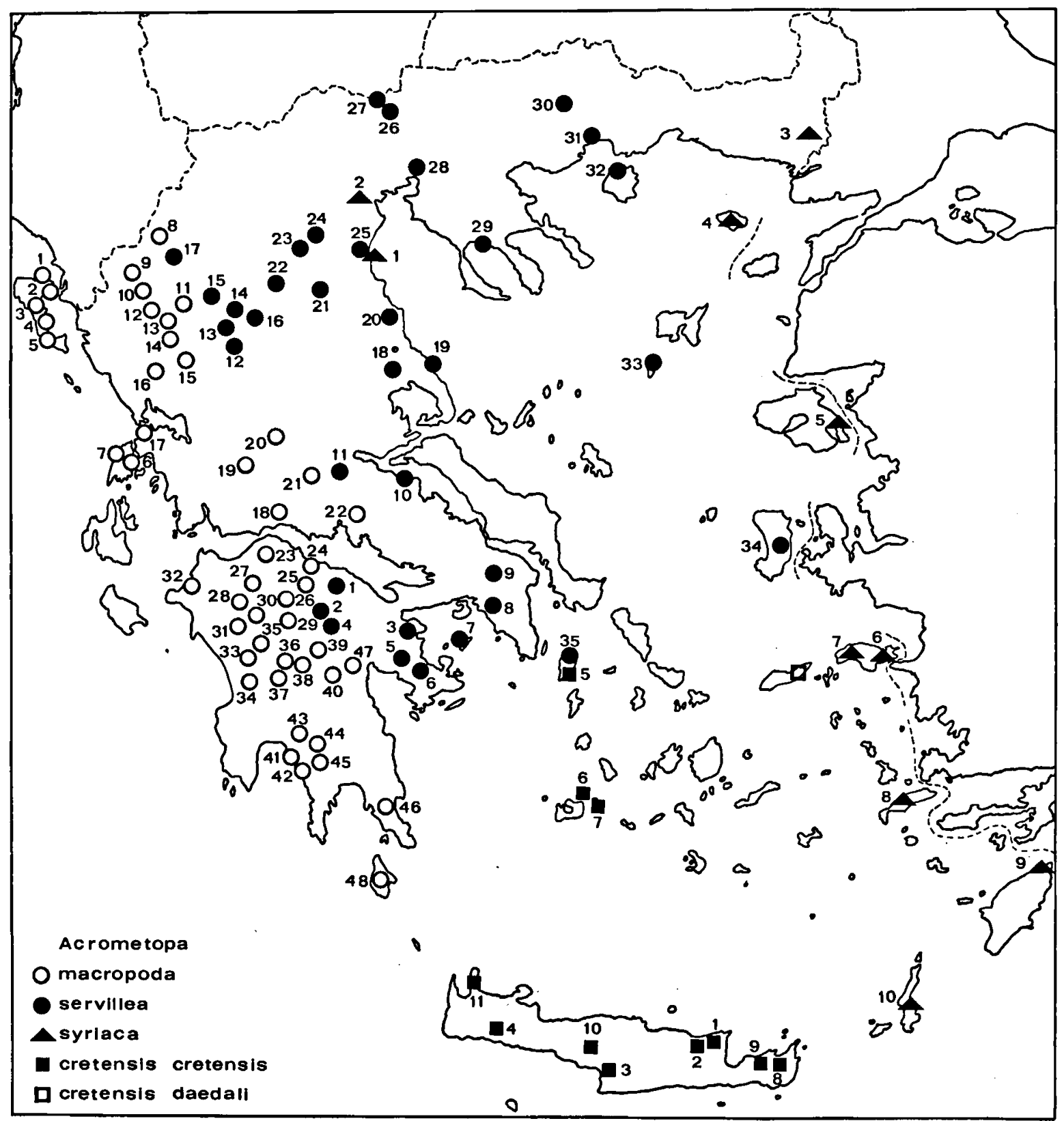

Map. The distribution of Acrometopa in Greece. 
- 1882. Prodromus der europäischen Orthopteren: $\mathrm{i}-\mathrm{xxxii}$, 1-466, figs. (Engelmann, Leipzig).

- 1891. Additamenta zur Monographie der Phaneropteriden. Verh. zool.-bot. Ges. Wien, 1891: 1-196, figs.

Burmeister, H., 1838. Handbuch der Entomologie, 2: 397. 1050. (Enslin, Berlin).

BurR, M., 1916. Field notes from Saloniki. Ent. Rec., 28: 189-193.

Burk, M., B. CAMpbell \& B. Uvarov, 1923. A contribution to our knowledge of the Orthoptera of Macedonia. Trans. ent. Soc. Lond., 1923: 110-169, map.

CEJCHAN, A., 1963. Ergebnisse der Albanien-Expedition 1961 des Deutschen Entomologischen Institutes, 10. Saltatoria. Beitr. Ent., 13: 761-796.

Fieber, F., 1853. Synopsis der europäischen Orthopteren. Lotos, 3: 90-104, 115-129, 138-154, 168-176, 184-188, 201-207, 232-238, 252-258.

Fischer, L. H., 1853. Orthoptera Europaea. i-xx, 1-454, figs. (Engelmann, Leipzig).

Giglio-Tos, E., 1893. Viaggio del Dr. E. Festa in Palestina, nel Libano e regioni vicine, 5. Ortotteri. Boll. Musei Zool. Anat. comp. R. Univ. Torino, 8 (164): 1-18, figs.

Harz, K., 1969. Die Orthopteren Europas, 1: i-xx, 1-749, figs. (Junk, The Hague).

JANNONE, G., 1936. Nuovi contributi alla conoscenza della fauna dell' isole italiane dell'Egeo, 5. Studio bio-ecologico e sistematico dell'Ortotterofauna con notizie sui Blattodei, Mantoidei e Fasmoidei. Boll. Lab. Zool. gen. agr. R. Scuola Agric. Portici, 29: 47-248, figs.

KALTENBACH, A., 1965. Dictyoptera und Orthopteroidea von Nordost-Griechenland und der Insel Thasos. Annln. naturh. Mus. Wien, 68: 465-484, figs.

- 1967. Mantodea und Saltatoria aus Griechenland. Annln. naturh. Mus. Wien, 70: 183-199, fig.

Krauss, H., 1878. Die Orthopteren-Fauna Istriens. Sber. Akad. Wiss. Wien, (1) 78: 451-544, figs.

KuthY, D., 1907. Insectorum messis in insula Creta a Lud. Birocongregata, 1. Orthoptera. Annls. Mus. nation. hungar., 5: 551-555.

LA GrecA, M., 1959. L'Ortotterofauna Pugliese ed il suo significato biogeografico. Memorie Biogeogr. adriat., 4: 33-170.

RAGGe, D., 1955. The wing-venation of the Orthoptera Saltatoria with notes on dictyopteran wing-venation: $\mathrm{i}$-vi, 1-159, figs. (British Museum (Natural History), London).

Ramme, W., 1927. Die Dermapteren und Orthopteren Siziliens und Kreta. Eos, Madr., 3: 111-200, figs.

- 1939. Beiträge zur Kenntnis der palaearktischen Orthopteren Fauna (Tettig. u. Acrid.), 3. Mitt. zool. Mus. Berl., 24: 41-150, figs.
SALFI, M., 1929. Richerche faunistiche nelle isole italiane dell'Egeo. Ortotteri. Archo. zool. ital., 13: 211-218, figs.

—, 1937. Ortotteri di Valona (Albania) e di Rodi (Egeo). Annuar. Mus. zool. Univ. Napoli (n.s.), 7: 1-6, figs.

SERville, J., 1839. Histoire naturelle des insectes Orthoptères. In: RORET, Collection des suites à Buffon: i-xviii, 1-776, figs. (Paris).

Uvarov, B., 1923. See: Burr, B. Campbeli \& B. Uvarov.

- 1935. The Malcolm Burr collection of palearctic Orthoptera. Eos, Madr., 11: 71-96, figs.

Werner, F., 1901. Die Dermapteren- und Orthopterenfauna Kleinasiens. Sber. Akad. Wiss. Wien, (1) 110: 259306 , figs.

- 1902. Beiträge zur Kenntnis der Orthopterenfauna Griechenlands. Berl. ent. Z., 47: 111-118, figs.

- 1927. Zoologische Streifzüge in Attika, Morea und besonders auf der Insel Kreta, 1. Orthopteren. Abh. naturw. Ver. Bremen, 26: 426-431.

- 1933a. Ueber Orthopteren aus Ost-Griechenland und von den Inseln des Aegaeischen Meeres. Mitt. zool. Mus. Berl., 18: 395-415, figs.

- 1933b. Ergetnisse einer zoologischen Studien- und Sammelreise nach der Inseln des Ägäischen Meeres, 2. Orthopteren. Sber. Akad. Wiss. Wien, (1) 142: 185204.

—, 1934. Dritter Beitrag zur Kenntnis der Tierwelt der Ägäischen Inseln. Sber. Akad. Wiss. Wien, (1) 143: 313-337, figs.

—_ 1936. Ergebnisse einer zoologischen Forschungsreise nach dem Dodekanes, unternommen von Kustos Dr. Otto Wettstein, 1. Orthopteren aus dem Dodekanes. Sber. Akad. Wiss. Wien, (1) 145: 9-16.

- 1937a. Beiträge zur Kenntnis der Tierwelt des Pelopones, der Inseln Kythira und Euboea sowie der kleinen Inseln im Saronischen Golf. Sber. Akad. Wiss. Wien, (1) 146: 135-153, figs.

- 1937b. Ergebnisse der vierten zoologischen Forschungsreise in die Ägäis (1936). Sber. Akad. Wiss. Wien, (1) 146: 89-118, figs.

- 1938 . Ergebnisse der achten zoologischen Forschungsreise nach Griechenland (Euboea, Tinos, Skiathos, Thasos usw.). Sber. Akad. Wiss. Wien, (1) 147: 157173, figs.

WILlemse, F., 1977. Interesting distribution records of Orthoptera from the Greek mainland and some neighbouring islands. Ent. Ber., Amst., 37: 52-59.

Willemse, F. \& G. Kruseman, 1976. Orthopteroidea of Crete. Tijdschr. Ent., 119: 123-164, figs. 